\title{
Documenting the Unauthorized: Political Responses to Unauthorized Immigration
}

\author{
*Nicole Rae Baerg \\ University of Essex \& University of Mannheim \\ nicole.baerg@essex.ac.uk
}

$\&$

Julie L Hotchkiss

Federal Reserve Bank of Atlanta \& Georgia State University

julie.1.hotchkiss@atl.frb.org

$\&$

Myriam Quispe-Agnoli

Mercer University

quispe_mj@mercer.edu

\footnotetext{
${ }^{*}$ The views expressed here are the authors and not necessarily those of the Federal Reserve Bank of Atlanta or the Federal Reserve Bank System. The authors gratefully acknowledge Fernando Rios-Avila, Kalee Burns, Julia Schein, Yanling Qi, Alyssa Taylor, and Francis Wong for research assistance. They also thank Luisa Blanco, Jason Eichorst, Albert Fang, Jeff Frieden, Michael Giles, Zac Greene, Mark Hallerberg, David Leblang, James Lo, Will Lowe, Yotam Margalit, Caitlin Myers, Erica Owens, Maggie Peters, Sandra Orozco-Aleman, and two anonymous reviewers for helpful comments.
} 


\begin{abstract}
Cultural prejudice rather than self interest is the conventional wisdom for why voters respond negatively to immigration. Using a new measure of unauthorized immigrants based on self-reported invalid social security numbers, we show that voters' responses are more nuanced than mere prejudice against minorities. Using county level data from the U.S. state of Georgia, we find that voters in counties with above median levels of unauthorized workers are more likely to support the Republican party. We also find that wealthier counties and wealthier voters are most likely to respond negatively to the unauthorized. Our evidence warns against arguments that depict opposition to immigration as motivated solely by xenophobia and cultural fears among lower income whites.
\end{abstract}




\section{INTRODUCTION}

Electoral opposition to immigration is mounting, as evidenced by recent elections in Germany, Austria, Britain, and the United States. While the U.S. is clearly not alone in struggling with immigration issues, the implication of unauthorized immigration, or those without official legal documentation, became particularly pertinent in U.S. elections as the population share of unauthorized immigrants has grown by over 200 percent over the last 20 years (Krogstad and Passel, 2014). Most recently, Republican President-elect Donald Trump has advocated a policy of mass deportations, showing the high salience of immigration policy in U.S. elections (Hirschfeld Davis and Preston, 2016). In addition to election outcomes, an influx of unauthorized immigration has also led to profound policy changes within U.S. states. Between 1990 and 2012, a majority of U.S. states have adopted policies directly aimed at restricting unauthorized immigrants' access to jobs, education, and social services (NCSL, 2005; Passel, Cohn, Krogstad et al., 2014).

Social science research demonstrates considerable disagreement about why the electorate opposes immigration so fiercely. Is opposition to immigration based solely on ethnocentric prejudices and xenophobia or do voters also worry about competition over economic resources? More specifically concerning the unauthorized, is opposition to unauthorized immigrants in the U.S. thinly veiled racial prejudice against Hispanics, or alternatively, concerns about school quality, jobs, and social welfare spending (see for e.g. Borjas, Freeman, and Katz, 1991; Brader, Valentino, and Suhay, 2008; Campbell, Wong, and Citrin, 2006; Mayda, 2006; Perez, 2010; Scheve and Slaughter, 2001; Valentino, Brader, and Jardina, 2013)? Recently, scholars have provided evidence that economic explanations for why people oppose immigration are not as well supported as alterna-

tive explanations based on cultural factors (Card, Dustmann, and Preston, 2012; Hainmueller and Hangartner, 2013). As a result, racial prejudice and cultural fears are now the dominant explanations for why voters hold anti-immigrant sentiments and vote in elections for anti-immigrant parties and politicians (see also Hainmueller and Hiscox, 2010). 
Despite these findings, there are still many reasons to expect that voters might respond electorally to inflows of unauthorized immigrants based on real or perceived economic threats (Burns and Gimpel, 2000). Furthermore, while all natives are expected to oppose low skilled immigration, those natives who have low skills, and by association, lower incomes, might be expected to oppose immigration the most. Reasons why include arguments that the poor hold more nativist views (Malhotra, Margalit, and Hyunjung Mo, 2013; Margalit, 2012; Sanchez, 1997). The poor may also have more to lose from immigration, competing for jobs and social services with incoming unauthorized migrants (Dancygier and Donnelly, 2013; Goldstein and Peters, 2014). Additionally, wealthier voters may experience greater social pressures to appear less prejudiced and more cosmopolitan, tilting evidence in favor of greater prejudice by those with lower incomes as a consequence of social desirability bias in answering surveys (An, 2015).

On the other hand, scholarship on globalization and inequality suggests that inflows of low skilled immigrants might activate feelings of redistributive pressures among natives with higher rather than lower income levels (Alderson and Nielsen, 2002; Bearce and Laks Hutnick, 2014; Hatton and Williamson, 1998). If inflows of unauthorized workers are low skilled, an increase in low skilled immigration will lead to a rise in income inequality, which can increase pressures for redistribution and prompt protection of the fiscal purse among the native born (see for e.g. Bearce and Laks Hutnick, 2014; Borjas, 1987, 1999; Xu, Garand, and Zhu, 2015). Further, an increase in income inequality is positively associated with increases in political polarization, political mobilization among the wealthy, and the adoption of more conservative tax preferences (Becker, 1983; Cheung and Cunningham, 2011; Facchini and Mayda, 2009; Hanson, Scheve, and Slaughter, 2007; McCarty, Poole, and Rosenthal, 2003; Roemer et al., 1995). As distinct from arguments based on xenophobia or threat of low-skilled labor substitution, an influx of low skilled immigration might then be positively associated with anti-immigrant behaviors and sentiments among those natives with higher rather than lower incomes, as, under a progressive tax system, it is these voters that have a stake in mobilizing against redistributive policies. 
To date, researchers have largely failed to uncover a strong empirical relationship between higher incomes and opposition to immigration (Hainmueller and Hiscox, 2010). However if voters, and especially wealthier voters, are able to successfully mobilize against future redistribution by supporting tax-conservative political parties today, then the link between immigrants, tax rates, and expenditures may very well be negated. In fact, preemptive opposition by wealthy voters may explain why we see a negative (as opposed to positive) correlation in state welfare expenditure and declining tax rates alongside an increase in the immigrant population (Hainmueller and Hiscox, 2010, Figure 1, p.66). Related, researchers have shown evidence of a strong positive relationship between low skilled immigration and income inequality (Card, 2009) and between income inequality and political polarization (McCarty, Poole, and Rosenthal, 2003). As a consequence, there remain important motivations for why an influx of unauthorized immigrants might spur electoral support for anti-immigrant parties in elections, especially among the wealthy, for economic reasons.

In order to test this hypothesis, we examine the effect of unauthorized immigrants on Republican vote share in elections over time at the county level in the U.S. state of Georgia. Our primary contribution is the use of new firm-level data containing self-reported social security numbers in order to estimate the number of unauthorized immigrants formally employed in a voter's county of residence. We do this by assessing whether or not workers in the county report a valid social security number to their employer. We identify workers as "unauthorized" if they report an invalid social security number. We then use the average share of unauthorized workers across firms to proxy the population share of unauthorized immigrants in the county. Importantly, the number of the unauthorized in a county is distinct from the number of Hispanics (the ethnic group to which a majority of the unauthorized in the U.S. belong). Thus, our research design can uniquely account for both the potential influence of a greater population share of Hispanics (cultural threat) and the potential fiscal threats posed by a greater number of the unauthorized at the same time. ${ }^{1}$

\footnotetext{
${ }^{1}$ The 2008 American Community Survey (ACS) estimates that 11.4 million people in the U.S. were born in Mexico
} 
Furthermore, since the unauthorized population is not allowed to vote, we need not worry about their own voting behaviors. Finally, as the unauthorized (in the U.S.) tend to be low skilled or work in low skilled occupations, we can be sure to identify those immigrants most likely to contribute to growing income inequality and that are expected to garner broad opposition by both wealthier and poorer natives.

Our findings estimate that controlling for the Hispanic population share in a county, a one percentage point increase in unauthorized immigration corresponds to a 1.6 percent increase in Republican vote share in the next Congressional election in those counties where there is an above median share of unauthorized immigrants. We find that wealthy respondents living in areas with a large population share of unauthorized are most likely to vote for the Republicans in elections, the political party that is tougher on immigration and supports lower taxes, and this effect is stronger the higher the county median income. These results are also supported by survey evidence where we find similar results at the individual level. In all, we find evidence that while ethnic prejudice against Hispanics is indeed prevalent, economic concerns continue to matter. The key conditions we find are that the immigrant threat must be present (i.e. the population must be above a certain population threshold), and opposition to unauthorized immigrants is expressed most strongly by those living in wealthier areas and among those with higher incomes. Such evidence warns against arguments that depict opposition to immigration in the U.S. or abroad as motivated solely by xenophobia and cultural fears among lower income whites.

\section{THEORETICAL FRAMEWORK}

The literature on immigration offers disparate explanations for why we see variation in op-

CPS2008. The Department of Homeland Security (DHS) estimates that 7.03 million unauthorized immigrants from Mexico were in the U.S. in 2008. From these two sources, we estimate that an upper bound for the percent of Mexicans (born in Mexico) in the U.S. that is unauthorized is 60 percent. Also see Hoefer, Rytina, and Baker (2012). Similarly. a 2008 study from the Multilateral Investment Fund (MIF), which is administered by the Inter-American Development Bank, estimates that 47 percent of Latin American and Caribbean immigrants living in the United States are undocumented (cited in Mandelman and Nosal, 2008). 
position to immigration over time and across communities. One strand of the literature focuses on the types of characteristics that the native born prefer as a result of either ethnocentric attitudes or implicit biases; the literature often calls these factors cultural explanations of opposition to immigration. According to this view, natives' opposition to immigrants critically depends on the personal characteristics of the migrants themselves, with natives holding preferences for certain types of characteristics over others including: education, religious background, race and or ethnicity, and country of origin (Hainmueller and Hangartner, 2013). Preferences for immigrants from certain countries of origin or ethnic backgrounds as compared to other countries of origin or other ethnic backgrounds is termed "prejudice." A second strand of literature focuses on material or redistributive threats to the native born that results from competition over economic resources and or changes to factor payments as a result of influxes of foreign sourced labor. The literature often refers to this second mechanism as activating "material interests" or economic threats.

In this paper, we focus on examining whether natives' material interests over fiscal policy are linked to changes in elections. Fiscal concerns are expected to be associated with higher rather than lower income areas and earners and so we directly test this. There is mixed evidence on how (or whether) immigrants affect natives' wages. Some find that an influx of immigrants leads to reductions in low skilled wages among the native born (Borjas, 1999) whereas others find little to no effect (Card, 2009). In the case of Georgia, recent evidence shows that an influx of the unauthorized marginally increases (rather than decreases) wages among low-skilled, documented workers (Hotchkiss and Quispe-Agnoli, 2013). Much of this literature, however, focuses on the direct effects that immigrants have on individual labor outcomes while typically ignoring changes in income inequality. Importantly, because unauthorized workers occupy the lowest skill level in the labor market, this allows us to link the population size of the number of unauthorized with growing income inequality in the state.

In theories of prejudice, the poor are expected to oppose immigration more than the rich. Hainmueller and Hiscox (2010), for example, find that while all natives tend to oppose low skilled 
immigration, low skilled, lower income natives are most likely to express opposition to immigration. There are a number of possible explanations for why. One possible reason is that the poor may hold more nativist views and experience globalization processes with greater degrees of anxieties and cultural fear (Malhotra, Margalit, and Hyunjung Mo, 2013; Margalit, 2012; Sanchez, 1997); these anxieties may prompt lower income voters to turn against newcomers in elections. Second, poorer individuals may be more susceptible to manipulation of feelings of prejudice by political elites and the media, which can encourage ethnocentric behaviors and attitudes (Mendelberg, 2001; Newman and Velez, 2014; Valentino, Hutchings, and White, 2002); this would make lower income counties and individuals most likely to vote for the Republicans. Third, at the individual level, those with lower incomes are also expected to be less tolerant of inter-mixing among races, which is taken as evidence of lower tolerance towards minorities. Tolsma, Lubbers, and Coenders (2008), for example, find that individuals with lower educational levels are more prone to oppose inter-ethnic marriage than individuals with higher educational levels; this again would mean that lower income white counties would be most likely to vote for the Republicans as well as those with lower incomes. Finally, the percentage of the poor who express cultural fears may just be higher in surveys. Using a survey, An (2015) finds evidence that wealthier people are more susceptible to social desirability bias. What this means is that wealthier respondents may be more attuned to express lower levels of prejudice when answering survey question irrespective of how much prejudice they may actually feel, tilting evidence of ethnic fears in the direction of the poor.

An additional explanation for why poorer individuals and locales oppose immigration, and in particular unauthorized immigration, is competition for jobs and wages - labor market competition. Concerns over job competition or opposition to the unauthorized due to downward pressure on wages fall under the umbrella of "material interests" as opposed, or in addition to, prejudice. Some find that an influx of immigrants leads to reductions in low skilled wages among the native born (Borjas, 1999) whereas others find little to no effect (Card, 2009). There is, however, some evidence that vulnerable labor market conditions increase anti-immigration sentiment (Muller and 
Espenshade, 1985).

Alternatively, according to theories of fiscal threats, high income natives will oppose low skilled immigration as it is the higher income individuals that pay a greater share of their income into a progressive tax system and implicitly do not want to pay more taxes in order to support low skilled immigrants (Facchini and Mayda, 2009; Hanson, Scheve, and Slaughter, 2007; Mayda, 2006). Scholars have found that Hispanics serve as a good predictor of support for restrictive fiscal policy (Burns and Gimpel, 2000; Citrin, Green, Muste et al., 1997; Hood III and Morris, 1998; Valentino, Brader, and Jardina, 2013); that voters are motivated by fiscal concerns when it comes to advocating English language policies in the classroom (Campbell, Wong, and Citrin, 2006); and that restricting access to social services is popular in those counties with either a mix of ethnic groups and counties with above average Hispanic population (Tolbert and Hero, 1996). Similarly, studies have shown that the wealthy are also most likely to mobilize politically against higher taxes (Becker, 1983; Cheung and Cunningham, 2011; Roemer et al., 1995); that prospects of upward social mobility can render individuals far less supportive of redistribution than they otherwise would be (Benabou and Ok, 2001); and that growing income inequality also increases social pressures among the middle and upper classes to emulate the tax preferences of the wealthy (Corneo and Gruner, 2000).

As the unauthorized are primarily low skilled or work in low skilled jobs, an increase in unauthorized workers will increase the population share of workers in the lower, left-hand tail of the skill distribution, increasing income inequality. Further, because the unauthorized are grouped at the low end of the skill distribution, they are also expected to have a more visible effect on wage inequality among all workers (Xu, Garand, and Zhu, 2015). Using an across-country sample, scholars have found that an increase in income inequality is a good predictor of political pressures for redistribution (Alderson and Nielsen, 2002; Bearce and Laks Hutnick, 2014; Hatton and Williamson, 1998). In the U.S., scholars have also shown a positive relationship between income inequality and widening political polarization, with richer voters gravitating towards the Repub- 
lican party (McCarty, Poole, and Rosenthal, 2003). Furthermore, the U.S. South is particularly sensitive to changes in party vote share as a response to changes in income. Gelman, Shor, Bafumi et al. (2007, p.354), find that “... southern states show the strongest relations between county income and Republican vote share."

As our argument depends on the link between increases in the population of the unauthorized and electoral support for the Republicans as a result of increases in inequality, Table A.3 shows the relationship between state level income inequality in the U.S. state of Georgia and our measure of the unauthorized from 1990 to 2011. The simple OLS regression analysis examines the effect of the unauthorized on household income inequality measured by the Gini coefficient. To ensure this correlation is robust, we ran two different models, one controlling for state level GDP and a second controlling for per person welfare expenditure. As in previous literature, we find a positive relationship between the population share of the unauthorized and household income inequality. Such a correlation suggests that natives may indeed perceive increases in redistributive pressures and feelings of fiscal threat in the presence of the unauthorized. This relationship also corroborates recent findings by $\mathrm{Xu}$, Garand, and Zhu (2015) who find a similar relationship between immigration and income inequality across all U.S. states.

There are a number of possible criticisms of this argument, however, that also need to be addressed. First, estimates suggest that immigrants have a net negligible effect on fiscal spending (estimates put the actual impact as big as 0.5 percent of GDP per year) calling into question how much "real" threat natives actually feel (Auerbach and Oreopoulos, 1999; OECD, 2013; Tingley, 2013). As a result, it is possible that natives respond to perceptions of fiscal threats rather than actual fiscal threats. Despite this and as shown above, there is a positive correlation between inequality and the number of unauthorized which can then be interpreted by natives as pressures for redistribution. Another critique is that feelings of fiscal burden depends on the native population responding to real-world changes in demographics, such as changes in the population size. In other words, in order for voters to feel threatened from immigration, there must be an actual stimulus 
that creates the feelings of threat in the first place. Citizens may not actually know the size or numbers of immigrants, or may incorrectly estimate their numbers, which calls into question the underlying mechanism of competition. Hopkins, Tran, and Williamson (2014), for example, show that natives cannot correctly estimate the number of immigrants in a geographical area, whereas other research finds that substantial or drastic changes in the size of immigrant groups over time does indeed correctly capture local attention (Newman and Velez, 2014). Importantly, even when local communities cannot correctly estimate actual demographic shifts, mistakes seem to be biased in such a way as to emphasize rather than de-emphasize group threats from immigration. For example, in a recent study of 14 countries, researchers find that citizens estimate the actual number of immigrants as being two-times greater and that the American respondents incorrectly estimated that 32 percent of the U.S. population are immigrants when the actual immigrant population is closer to 13 percent on average (MORI, 2014). Finally, immigrants may avoid moving into hostile areas, reducing the possible in-group and out-group tensions in the first place. Using a crosscountry sample, Fitzgerald, Leblang, and Teets (2014) show that migrants are less likely to move into areas that have conservative governments. At the county level, however, we observe significant variation in the population size of the unauthorized and Republican vote share across counties in the state of Georgia, suggesting ample variation across the state (see Figure 1).

In summary, scholars have shown that natives are particularly opposed to immigrants, and while cultural reasons are expected to dominate, economic factors may indeed still matter. In the next section, we present an empirical design that tries to tease apart the multifaceted ways in which natives' electoral behaviors and attitudes towards the unauthorized are associated with changes in the population share of the unauthorized across counties in the U.S. state of Georgia. We distinguish between cultural threats, labor market threats, and fiscal threats by accounting for the unauthorized and Hispanic share of the population simultaneously in the same empirical model. Evidence of additional threats felt by voters from the presence of unauthorized immigrants, over and above that by Hispanics, suggests that voters perceive the unauthorized as an additional 
threat to their economic interests. Furthermore, if threat is based only on natavist fears or job competition, we should see a stronger reaction from poorer counties and voters. If, by contrast, threat is based also on fiscal concerns, real or perceived, then we should see an independent reaction from richer counties and voters, as it is the wealthy that bear the greater fiscal burden through the progressive tax system, and thus the wealthy should have more incentives to mobilize against expected increases through a higher likelihood of voting for the Republicans. As a preview, our results provide evidence that wealthier communities react more dramatically to a greater presence of the unauthorized, and that these threats are independent of and in addition to more prevalent feelings of threat based on race and ethnic prejudices from the presence of Hispanics.

\section{METHODOLOGY}

\section{Identifying the Unauthorized}

In most research, the unauthorized population is a "hidden" or "hard to reach" community and as a result, the unauthorized are rarely accounted for. In population based survey data, for example, the unauthorized are more likely to have higher non-response rates than other survey respondents and are also less likely to be surveyed in the first place (Chavez, 2012; Cornelius, 1982). Second, even when the unauthorized are accounted for, they also have incentives to misreport their legal status and it is difficult for researchers to validate ex post the self reported immigration status of the respondent. In this paper, we are able to make use of a new measure of the unauthorized that overcomes these problems and we use this measure to examine how natives' responses to the unauthorized varies across different counties and across time.

At best, current estimates of the presence of unauthorized immigrants are available only at the national or state level (Passel, Cohn, Krogstad et al., 2014; Warren and Warren, 2013), whereas our measure is able to provide an estimate of the unauthorized at the county level. The data we use to construct our measure are the Employer File and the Individual Wage File, compiled by the Geor- 
gia Department of Labor for the purposes of administering the state's Unemployment Insurance (UI) program. The Employer File provides an almost complete census of firms in Georgia, covering approximately 99.7 percent of all wage and salary workers (Committee on Ways and Means, 2004). The firm-level information includes the number of employees, and the worker file includes the worker's Social Security Number (SSN), from which we determine whether the worker is authorized to legally work or not. ${ }^{2}$ Our measure captures a unique situation where the unauthorized have an incentive to report an invalid SSN so as to be able to collect wages they earned through employment in the formal labor market and that we, as researchers, can determine whether or not that $\mathrm{SSN}$ is a valid or invalid after the fact.

Every quarter, employers file a report with the state Department of Labor detailing all wages paid to workers who are covered under the Social Security Act of 1935. Each worker on this report is identified by his/her social security number ( $\mathrm{SSN})$. There are several known characteristics of a valid social security number, and we check whether each number worker's number conforms to these characteristics. ${ }^{3}$ The first three numbers of the SSN are the Area Number. This number is assigned based on the state where the SSN application was made. The lowest Area Number is 001 and the highest Area Number ever issued, as of December 2006, is 772. Using information provided by the SSA, we can determine the dates at which area numbers between 691 and 772 are first assigned. Any SSN with an Area Number equal to 000, greater than 772, or which shows up before the officially assigned date, is considered invalid. The second piece of a SSN consists of the two-digit Group Number. The lowest group number is 01 , and they are assigned in non-consecutive order. Any SSN with a Group Number equal to 00 or with a Group Number that appears in the

\footnotetext{
${ }^{2}$ Use of these data is restricted and while every state in the U.S. collects these data, we have access to data from the state of Georgia only. The data are confidential and cannot be directly accessed by any individual not employed by the Department of Labor, however, arrangements for accessing the data used in this analysis for purposes of replication can be made with the Director, Office of Research, at the Georgia Department of Labor. Similar data for Connecticut is used in Couch and Placzek (2010).

${ }^{3}$ Starting in June 2011, the Social Security Administration began constructing SSNs in a random fashion, so this identification of whether a SSN is valid or not is no longer possible.
} 
data out of sequence with the Area Number is considered invalid. The last four digits of a SSN are referred to as the Serial Number. These are assigned consecutively from 0001 to 9999 . Any SSN with a Serial Number equal to 0000 is invalid.

In 1996 the Internal Revenue Service (IRS) introduced the Individual Tax Identification Number (ITIN) to allow individuals who had income from the U.S. to file a tax return (the first ITIN was issued in 1997). It is simply a "tax processing number," and does not authorize an individual to work in the U.S. Employers are instructed by the IRS to "not accept an ITIN in place of a SSN for employee identification for work." An ITIN is only available to resident and nonresident aliens who are not eligible for U.S. employment and need identification for tax purposes. ITIN numbers have a "9" in the first digit of the Area Number and a "7" or " 8 " in the first digit of the Group Number. Anyone with this numbering scheme we identify as having an invalid Area Number. Interestingly, the percent of SSNs with high area numbers that also match the ITIN numbering scheme has risen from about one percent in 1997 to over 60 percent by the end of 2006.

A series of SSNs were de-commissioned by the Social Security Administration because they had been put on fake Social Security Cards used as props to sell wallets. Apparently, some people who purchased the wallets thought the fake Social Security Cards were real and started using them as their own. If any of these 21 "pocketbook" SSNs appear in the data, they are considered invalid, although their frequency is so low as to be inconsequential. In addition, a number of SSNs are exactly equal to the employer identification number. These are invalid, primarily because they have too few digits. In any instance where a SSN is used for more than one person on a firm's UI wage report or does not have the required number of digits (including zeros), the SSN is marked invalid.

The possibility that someone fraudulently uses a valid SSN assigned to someone else poses a special problem. First of all, the SSN will show up multiple times across firms in one quarter for workers with different surnames (the wage report includes the first three characters of the workers' surnames). With this information alone, it is not possible to know which worker is using the SSN 
fraudulently and who the valid owner of the number is. If one of the SSN/surname pairs shows up in the data initially in a quarter by itself, this is the pair that is considered valid and all other duplicates (with different surnames) are marked invalid.

This measurement strategy clearly under-counts the actual number of undocumented workers in Georgia, but we can draw on a couple of sources of external data to show that our sample of undocumented workers closely represents the presence of unauthorized immigrants in the state of Georgia and conforms broadly to the patterns in the U.S. as a whole as well. First of all, the rate of growth seen in both the number and percent of undocumented workers identified in Georgia matches closely the rate of growth in the Social Security Administrations (SSA) earnings suspense file (ESF). The ESF is a repository of Social Security taxes paid by employers that cannot be matched to a valid name or SSN. It is widely believed that this growth in the ESF reflects growing incidence of unauthorized work in the United States (Bovbjerg, 2006). Figure 2 plots the number of workers, and the percent of workers, respectively, identified as undocumented along with the size of the ESF (we plot numbers only through 2006, since that is the last year for which the ESF data are available). This figure shows a remarkable consistency between the growth seen in workers identified as undocumented and the ESF. As a second check, we also examine growth in remittance transactions from the U.S. to Mexico over the same time period and plot this with growth in the number of unauthorized workers as captured by our measure. As with the ESF data, Figure 2 shows a similar trend. ${ }^{4}$ Finally, we also compare our measure against population based estimates from country of origin. Some estimates are that between 40 and 60 percent of Mexicans (people born in Mexico) residing in the United States are undocumented, and similarly, that between 47 and 61 percent of unauthorized immigrants come from Mexico (Hoefer, Rytina, and Baker, 2012; Mandelman and Nosal, 2008). Clearly not all Hispanics are undocumented, or vice versa; however, using weighted data from the Current Population Survey (CPS), we calculate

\footnotetext{
${ }^{4}$ While we do not have remittance transaction data for the state of Georgia separately, according to a 2008 MIF survey, approximately 47 percent of undocumented workers send remittances home (MIF, April 2008).
} 
the average annual growth in total workers and total number of foreign-born, Hispanic workers in the United States and in Georgia to compare growth rates to those in our sample in order to provide another validity test for our measure of the presence of unauthorized immigrants in Georgia. These results are reported in Table 1. The work force in GA grew faster over the period than the U.S. work force (2.9 vs. 1.5 percent). In addition, the number of foreign-born, Hispanic workers in the United States grew faster (8 percent per year) than the overall work force; other researchers have also documented this phenomenon (Passel and Cohn, 2009). But most importantly for our purposes is that the growth rate of foreign-born, Hispanic workers in Georgia (roughly 27 percent per year), which is much larger than in the United States overall and is similar to the growth in the number of workers in Georgia we classify with our measurement strategy. We also observe a similarly large growth rate in the number of foreign-born, Hispanic workers with less than a high school degree (21 percent), among which we might expect a larger share of undocumented workers than among foreign-born, Hispanics in general.

\section{Empirical Model}

In this section, we test for whether or not we observe evidence of an economic threat effect given a larger demographic presence of the unauthorized while controlling for possible cultural concerns. We also examine whether it is poorer or wealthier counties that react most strongly. So as to make sure that we are capturing actual behaviors at the individual level, using survey data, we also explore the impact of a change in the number of unauthorized on natives' attitudes towards the unauthorized using social-services.

The statistical analysis is performed at the county level. An increase of support for Republicans within a county can occur for a number of reasons. First, voters can change their partisan preference from Democrat to Republican. Second, Democrats can become less likely to vote. Third, Republicans can become more likely to vote, and finally, Democrats can move out or Republicans can move into the county. The first three sources of increasing support for Republicans result 
from changes in voting behavior - either voting differently or voting more or voting less. The fourth source does not result from changing voter behavior and can confound our interpretation; we specifically address the possibility of this confounding effect in our analysis on in and out migration in our Robustness Checks.

The dependent variable of interest, election outcomes, measures every vote for Governor, U.S. Congress, or U.S. Senate at the county level as the share of Republican votes relative to the total number of votes cast for either the Republicans or the Democrats. We use the proportion of votes as our main measure, because it captures information about the intensity with which voters prefer the Republicans over the Democrats or the converse. The election data are obtained from the Georgia Secretary of State website. ${ }^{5}$ The analysis in this paper considers Gubernatorial, U.S. Senatorial, and U.S. Congressional elections by county in the state of Georgia that took place between 1990 and $2010 .^{6}$

The main explanatory variable is the average share of workers employed by firms that is unauthorized. We use this variable as a proxy for the share of unauthorized immigrants in the county. We also want to account for the fact that some counties are wealthier than others. We therefore, include median household income obtained from the U.S. Census, Small Area Income and Poverty Estimates. $^{7}$ We also control for the racial composition of counties using data from the U.S. Census Bureau Population Estimates. $^{8}$

Figure 1 shows the variation in the unauthorized immigration across Georgia counties in 2010. As we can see, there is significant variation; the median share of unauthorized workers is 0.51

\footnotetext{
${ }^{5}$ www.sos.ga.gov/elections

${ }^{6}$ We report only the Congressional results in the body of the paper but the Senatorial and Gubernatorial results are included, with other robustness checks, in Table A.1 in the Appendix.

${ }^{7}$ We match median household income in a given county for an election year. Each variable contains one observation for each Georgia County for each year between 1989 and 2011, with the exception of the years 1990, 1991, 1992, 1994, and 1996. For observations for each of these five missing years for each county, we impute the missing data and recover estimates of median household income.

${ }^{8} \mathrm{http}: / /$ www.census.gov/popest/data/historical/index.html
} 
percent across the entire sample and ranges from 0 to 17 percent, with some counties having an average share of unauthorized workers below the median (those counties with lighter shades), and some counties with average shares above the median, (those counties with darker shades). Also shown in Figure 1, we see that while the Republican party dominates across the state in Congressional elections, there is still large across-county variation in Republican vote share. In addition, Figure 3 maps the distribution of Median Household Income by county and the population share that is black. While the correlation between income and population share of blacks is negative $(-0.4)$, there are counties in Georgia that are predominately white and poor as well as counties in Georgia that are predominately black and affluent. This is especially true for those affluent black communities located in the greater Atlanta metropolitan region.

The statistical analysis involves estimating the following logistic regression model via Generalized Linear Methods (see Baum (2008); Maddala (1983)):

$$
\begin{aligned}
& \ln \frac{\text { RepShare }_{i, j, t}}{\left(1-\text { RepShare }_{i, j, t,}\right)}=\beta_{0}+\beta_{1} \text { PerUndoc }_{i, t-2}+\beta_{2} \text { PerHisp }_{i, t-2}+\beta_{3}^{\prime} X_{i, t} \\
& +\beta_{6} \text { RepShare }_{i, j-1}+\beta_{5} \text { RepIncumb }_{i, j}+\beta_{6} \text { EmpGrth }_{i, t}+\beta_{7} \text { NearPerUndoc }_{i, t} \\
& +\delta_{1} E_{j}+\delta_{2} C_{i}+\epsilon_{i, j, t}
\end{aligned}
$$

RepShare is the share of the vote in county $i$ in election $j$ in year $t$ that accrues to the Republicans. The coefficients from this estimation are interpreted as the marginal effect of the regressor on the log-odds ratio of RepShare. However, since our interest is not on the odds of the Republicans receiving one hundred percent of the vote, which is what the log-odds tells us, we report the marginal effect of the regressors of interest on a percentage point change in RepShare. ${ }^{9}$

The regressor of interest, average percent of workers that is unauthorized, has the potential of

\footnotetext{
${ }^{9}$ The average marginal effect on Republican vote share from a change in regressor $k$ is calculated as follows: $\frac{\partial R e p \text { Share }}{\partial X_{k}}=\hat{\beta}_{k} \frac{e^{-(\hat{\beta} \Omega)}}{\left[1+e^{-(\hat{\beta} \Omega)}\right]^{2}}$, where $\hat{\beta} \Omega$ is the linear prediction for RepShare from the GLM estimation.
} 
being endogenous to the Republican share of the vote in that county. While the potential for voting behavior of the population group of interest (unauthorized immigrants) affecting the outcome is not a concern here, as unauthorized immigrants do not vote, the data are not a panel of individual voting behavior. Consequently, we only know the share of votes going to Republicans at each election conditional on the composition of voters in the county during that election. Rather than a change in voting behavior within a county, out-migration of voters may occur as the result of the presence of unauthorized immigrants, changing the composition of voters within the county. Analysis on in- and out-migration described below addresses this specific concern. Additionally, we lag the regressor of interest, PerUndoc, to help avoid the possibility of reverse causality. We use a two-year lag in order to make the potential nearness of impact consistent across different types of elections that are held at different intervals.

We also include an election-lagged value of the dependent variable to account for potential serial correlation between election outcomes; this would also capture the average partisanship of the electorate. ${ }^{10}$

Other regressors, measured in the same year as the election, $X_{i, t}$, include real median household income in the county, adjusted for inflation, and the share of the population that is black. $\operatorname{RepIncumb}_{i, j}$ is a dummy variable indicating whether the incumbent for election $j$ is a Republican. We also include county employment growth, EmpGrth $h_{i, t}$, as a regressor in order to control for an obvious factor that might be influencing both Republican vote share and the presence of unauthorized immigrants. Similarly, to control for possible geographical clustering of the unauthorized or network effects, we also include the average size of the unauthorized population in neighboring counties as a control, NearPerUndoc $i, t$. These two regressors should help control for potential selection of the unauthorized to locate in particular counties.

\footnotetext{
${ }^{10}$ Nickell (1981) warns of bias that arises with the presence of the lagged dependent variable in fixed effects models with a small number of time periods. We re-estimate the models excluding the lagged dependent variable and the resulting estimated coefficients on the regressors of interest are essentially the same as those reported here. These and other robustness checks are available from the authors.
} 
In addition, both election and county fixed effects ( $E_{j}$ and $C_{i}$, respectively) are included to control for election specific (county invariant) and county specific (time invariant) determinants of the Republican share of the vote.

If voters view a larger presence of unauthorized immigrants in their county as a potential threat, turning them toward the Republican party, we would expect a positive estimate of $\beta_{1}$. In order to distinguish between the unauthorized low skilled immigrant threat from more general levels of possible threats induced by Hispanics, we include both the presence of unauthorized immigrants (PerUndoc) and the presence of Hispanics (PerHisp) in the same model, effectively holding constant any ethnocentric threat from Hispanics. Since it is estimated that up to $60 \%$ of Mexicans and roughly $47 \%$ of Latin American and Caribbean immigrants in the U.S. are unauthorized (see footnote 1), we interpret the residual variation in PerUndoc as capturing the influence of the presence of particularly low-skilled immigrants.

\section{EMPIRICAL RESULTS}

Table 2 contains the the marginal effects (see footnote 10) from estimating various specifications of equation 1 for U.S. Congressional elections. The results in column 1 suggest that there is little evidence of a prevalent threat effect from the unauthorized. In this model, only the Hispanic variable is substantively and statistically significant. Such a finding supports previous evidence that the prevalent fear among the native born is one that is sourced in anti-Hispanic, non-economic ethnocentric fears.

Once we restrict our attention to those counties that have a higher than median share of unauthorized immigrants, however, the prevalent threat effect is no longer the only thing that matters. When the population size of the unauthorized is substantially large (defined as $0.51 \%$, or the sam-

ple median share), we find that the unauthorized are also positively correlated with Republican 
vote share. ${ }^{11}$ Furthermore, this reaction to the presence of the unauthorized is substantively as well as statistically stronger than the threat effect estimated for Hispanics. Our finding gives further credence to previous evidence that finds substantial changes in the size of immigrant groups over time captures local attention and that areas respond with an increase in the vote share for the political party that is tougher on immigration and supports lower taxes. ${ }^{12}$

The results thus far suggest that voters may respond to actual changes in their communities. Like previous research we find that their responses are conditional on actual demographic changes rather than anxieties manifested across all counties (Malhotra, Margalit, and Hyunjung Mo, 2013). Among all counties, the share of vote going to Republicans increases by 0.6 of a percentage point for every percentage point increase in the population share of Hispanics. This suggests that there exists significant underlying cultural prejudice. In addition, as the share of unauthorized immigrants reaches and surpasses the median value across all counties ( 0.51 percent), we find that a one-percentage point increase in the share of unauthorized immigrants employed by firms in those counties results in a 1.55 percentage point gain in the Republican share of the vote in the next U.S. Congressional election - in counties with larger shares of unauthorized, the reaction to a percentage point increase in the unauthorized population is larger than to a percentage point increase in Hispanics. This suggests that in addition to a general feeling of cultural prejudice, voters are also reacting to a perceived threat to material interests when the share of unauthorized in their county reaches a certain threshold.

The average share of the Republican vote in Congressional elections varies from over 50 percent through the mid-1990s to roughly 59 percent in the 2000s. Passel, Cohn, and Gonzalez-

\footnotetext{
${ }^{11}$ These results are consistent with Mayda, Peri, and Steingress (2015) who, using state level data, find that higher shares of non-citizen immigrants decrease Republican share votes when the number of non-citizen immigrants is large.

${ }^{12} \mathrm{We}$ also run these same models in Senatorial and Gubernatorial elections and include them in a supplemental appendix. We find similar results for Senatorial elections but in Gubernatorial elections, the unauthorized is never a significant predictor of Republican vote share again supporting recent evidence linking immigration and Republican vote which is similar to findings in Hajnal and Rivera (2014). Mayda, Peri, and Steingress (2015) also find much stronger reactions to immigrants in Congressional House elections relative to Gubernatorial, Senatorial, or Presidential elections.
} 
Barrera (2013) estimate that the unauthorized population in Georgia increased from 3.1 percent in 2000 to 4.4 percent in 2010 (a 1.3 percentage point increase). ${ }^{13}$ Based on the estimates in Table 2, the influx of unauthorized might account for a gain of about two percent of the votes going to the Republicans for the U.S. Congressional candidate over this time period (1.3 times 1.55) - at least in counties with the largest shares of unauthorized.

Also in Table 2 we see that the Republican share of the vote is lower in counties with a greater share of black voters and with lower median household income, which is consistent with findings in the literature (see for example Gelman, Shor, Bafumi et al. (2007)). As might also be expected, as evidenced by the positive and significant coefficient on the lagged dependent variable, party identification is important. In addition, Republican incumbency is positive and significant, indicating a great deal of underlying electoral outcome inertia. The negative coefficient on the lagged dependent variable could be capturing the overall growth in Republican growth share from the previous period in most counties.

In order to figure out when such effects are most likely manifested, we also do sub-analysis for general and midterm elections. We report these findings in columns 3 and 4 . While the lack of power produces results not significant at conventional levels, the results for midterm elections are nearly seven times larger than those for the general elections, are roughly of the same magnitude as for the whole sample, and are statistically significant at the 88 percent confidence level, suggesting that it is midterm rather than general elections where the positive correlation is expressed most. There are a number of reasons for why this may be the case. The limited number of people who vote in midterm elections and the composition of voters who vote in midterm elections may also be those who worry most about an influx of immigrants. In particular, older, white, and wealthier individuals are more likely to vote in midterm elections and so our results may be capturing these characteristics (Jackson, Brown, and Wright, 1998). This supports survey evidence that finds that age is positively correlated with anti-immigrant sentiment (Hainmueller and Hangartner,

\footnotetext{
${ }^{13}$ Passel, Cohn, and Gonzalez-Barrera (2013)
} 
2013). Zingher and Steen Thomas (2014) also find that racial diversity might matter for elections. According to these authors, whites who live in heterogeneous precincts turnout to vote less than whites in homogeneous precincts, however racial segregation within the precinct matters also. Another explanation might be that we are picking up the dissatisfaction with the President's party and voters' greater willingness to vote against the incumbent. One problem with this argument, however, is that while it could explain a greater shift towards the Republicans during Clinton's tenure (1993-2001), it would not explain the shift to the Republicans during Bush's tenure (2001-2009) (Abramowitz, Cover, and Norpoth, 1986; Knight, 2014).

The identification of voters responding to a feeling of threat does not alone tell us whether that threat is related to fiscal concerns. In order to examine this, column 5 of Table 2 interacts the percent undocumented with median household income (adjusted for inflation). The results of the marginal effects indicate that increased support for Republicans is more pronounced the wealthier the county. Figure 4 shows the estimated marginal change in the expected Republican vote share as median household income in the county increases. We find that Republican vote share is more responsive to higher shares of unauthorized immigrants in more wealthy counties than it is in lower income counties. This suggests that opposition to the growing presence of the unauthorized is not dominated by labor market concerns, as those would expected to be more pronounced in poorer counties. In addition, Voters in more wealthy counties pay higher taxes, suggesting that the material interest we see reflected in column 2 is likely based on redistributive concern. Furthermore, we also see a stronger impact of the unauthorized compared to Hispanics as before. Also, as median household income and the percent of the population that is black are somewhat negatively correlated, we are likely capturing wealthy opposition to unauthorized immigration in higher-income counties comprised of white voters.

Finally, some scholars have found that voters in areas that were historically racist against blacks are also more likely to vote Republican, especially in the U.S. South. If historical legacy is correlated with modern opposition for immigrants, then voters' reactions could be reflecting historical 
prejudice rather than current response to unauthorized immigration (Acharya, Blackwell, and Sen, 2016; O'Connell, 2012; Reece and OConnell, 2016). The advantage of being able to use cross sectional time series data is that we are able to control for historical prejudice, as well as any other time-invariant correlates, through the inclusions of county fixed-effects. As another check to make sure that we are not capturing mere persistence in racial attitudes or historical prejudice, we rerun the analysis using the population percent of blacks in 1860 to weight the county observations. The effect is to place greater weight on those voters living in areas with higher historical levels of slavery. We find no practical differences in the results as shown by column 6 , suggesting that persistence in prejudice across generations is not the main driver of our results.

\section{ROBUSTNESS CHECKS}

The results above show that as the share of unauthorized immigrants in a county increases, the share of votes going to the Republican candidate in the next election also increases, providing support for explanations of material as well as non-material interests. However, we do not have a panel of individual vote data over time. Consequently, our results may be driven by voter mobility motivated by the presence of unauthorized immigrants. In addition, our results don't prove a link between opinions about unauthorized immigration and voting behavior. This section details further analyses designed to address these, and other, potential concerns.

\section{Reverse Causality?}

In the estimation, we include lags of the undocumented share in order to prevent against the possibility of reverse causality. As an additional test of whether it might be the case that the undocumented are drawn to counties with a higher share of Republicans (and whatever economic or social benefits that might bestow), we undertook a Granger causality test. Whilst not a test of "deep causality", we can use Granger causality measures to test for sequence. The results of the Granger and VAR test are presented in Table 3. Conducting these tests, we found that three lags 
(6 years) in each variable was sufficient. While we find that the number of undocumented (and the variables lags) improve the forecast of the county-level Republican vote share (as expected from the results presented above), we find little evidence that Republican vote share (and its lags) improve the forecast of the numbers of the undocumented. This provides additional evidence that the temporal ordering goes from changes in the shares of the unauthorized population to changes in Republican vote share rather than the converse.

\section{In and Out Migration?}

Faced with an increase in the number of unauthorized immigrants, it is possible that Democrats move out of the county if they experience greater economic threats than Republican voters. As a result of mobility, then, we might observe higher Republican support in counties with higher shares of undocumented workers, which would confound our interpretation. It is also feasible that owners of capital (likely to be Republicans) move into counties with higher numbers of undocumented workers as they offer a new source of inexpensive labor.

In order to check for the importance of migration, we examine inflow and outflows of individuals into counties using the Internal Revenue Service (IRS) county-to-county Migration Data. These data contain residential location information for 95 to 98 percent of the individual income tax filing population. For each county in Georgia, for each year, we know the number of people who moved into the county (inflow), the number of people who moved out of the county (outflow), and the number of people who remained in the county (non-movers). Data are available from 2005 through to 2010 .

If out-migration patterns are the mechanism at work behind the marginal effects in Table 2, then we should observe a positive correlation between the share of undocumented workers in the

previous year and the county's outflow percentage. Additionally, if owners of capital (Republicans) are moving into counties with higher shares of undocumented workers to take advantage of economic opportunities, then we should observe a positive correlation between the share of undoc- 
umented workers in the county and the inflow percentage. While this analysis does not identify the political affiliation of people moving from one county to another, a significant relationship between the presence of unauthorized immigrants and migration is a necessary condition to conclude that migration is driving our main results.

Table 4 presents the marginal effects from a logistic regression which allows us to control for other county characteristics and county and year fixed effects, in addition to the previous year's percent of unauthorized immigrants (again, proxied for by average share of undocumented workers within firms). We observe that the coefficient on lagged undocumented workers is positive in the outflow equation and negative in the inflow equation, but more importantly neither measure is statistically or substantively significantly. These results provide further evidence that as the share of undocumented workers increases, increased support for Republicans is not, at least primarily, being driven by migration patterns. We do note however, that there are other statistically significant relationships that appear in this estimation exercise. In-migration is lower to counties with a high share of blacks and higher in counties with a lower share of the vote going to Republicans in the previous election. This second results may be picking up growth in urban counties, which are less likely to vote Republican.

\section{Individual Attitudes?}

Another potential problem with making inferences about changing voter behavior from the results reported here is that the analysis relies on aggregate county level data and therefore cannot tell us about actual behavioral change linked to opinions; as a result, our analysis might suffer from ecological inference (King, 1997). One strategy to overcome this shortcoming is to examine differences in natives' sentiments towards the unauthorized at the individual level and to compare these micro-level results with the aggregate results above. The Cooperative Congressional Election Study (CCES) is a nationally stratified survey administered by YouGov/Polimetrix. In 2012, the survey asked a series of questions relating to immigration. Important for our purposes, one of the 
questions on immigration was related directly to unauthorized immigrants and respondents' opinions on restricting access to emergency medical treatment and public schools. In addition to this question, the survey also asks basic demographic and socio-economic questions including where the respondent lives, their family income, their gender, education level and whether or not they were employed. Matched with the same county level measure of unauthorized immigrants used for the main analysis, we use this survey question to test whether or not respondents' attitudes for restricting unauthorized immigrants from accessing publicly funded social services is associated with actual population share of the unauthorized. As the literature has stressed both macro and micro level explanations, we evaluate both individual and county level factors that may help predict restrictive attitudes towards immigration.

The text of the immigration question that we use asks respondents:

What do you think the U.S. government should do about immigration?

Prohibit illegal immigrants from using emergency hospital care and public schools.

The dependent variable is coded 1 if someone answers yes and 0 if someone answers no, and coding the dependent variable this way makes our findings directly comparable with previous research findings (see for e.g. Hanson, Scheve, and Slaughter, 2007; Tingley, 2013). However, this survey is unique in that it asks directly about illegal immigrants, rather than about immigrants in general. ${ }^{14}$ The sample of respondents that we use match the previous analysis and are individuals that reside in the state of Georgia. We match respondents with our county level data by county Federal Information Processing Standards (FIPS) code. The total number of unique respondents in the sample is 1789 . Out of this number, 1209 respondents (approximately 68 percent) report that they do not support restricting emergency hospital care and public schools. The remaining 550 respondents (approximately 32 percent), meanwhile, report that they do support restricting

\footnotetext{
${ }^{14}$ Unfortunately the CCES does not ask the same question in different waves and therefore a repeated cross-section design is not possible. Other surveys such as the ANES, while repeated, unfortunately do not ask about the relationship between illegal immigrants and restricting social services.
} 
social services to illegal immigrants. Georgia voters are not unique and hold views consistent with broader opinions about immigrants and welfare spending in the U.S. electorate. For example, in the 2008 American National Election Survey (ANES), 30 percent of respondents across the U.S. were concerned about Latino immigrants and their use of welfare services. ${ }^{15}$

Using the answer for this question as a measure of fiscal concerns triggered by the presence of unauthorized immigrants, we estimate a series of logit models to test individual and county level characteristics. In order to make sure that survey respondents are responding to the survey question that should raise feelings of immigrant-specific threats and not that we are tapping into mere correlation with other unaccounted-for attitudes, we run the same model on a number of other questions from the same survey. In other words, our results on unauthorized immigration may just be picking up the degree of respondent political "conservatism" which is unrelated to unauthorized immigrants and conservative respondents may happen to live proximate to unauthorized immigrants. In order to rule this out, we estimate exactly the same model but change the dependent variable from opposition to illegal immigrants using social services to whether respondents oppose gay marriage, oppose gun control, and oppose spending on Medicaid and Medicare. If our estimation is merely picking up general level partisan and fiscal conservatism, independent from the survey question, then we should see roughly the same results as for the unauthorized.

Our results are reported in Table 5. We find that counties with higher numbers of unauthorized immigrants, conditional on their income, are more likely to support restricting social services to illegal immigrants. ${ }^{16}$ This finding further supports our previous evidence; there is clearly higher opposition to immigration in those counties where the population share of the unauthorized is

\footnotetext{
${ }^{15}$ Tingley (See Table 2, 2013)

${ }^{16}$ We try two different measures of this conditional effect, counties with an above 1 standard deviation from the mean share of unauthorized and counties with an above median share are coded 1 and 0 otherwise. The results are significant only in the first specification and not the second. One explanation for the differences in thresholds when compared with the voting analysis may be that respondents are more likely to respond to social desirability bias in answering surveys making them less likely to speak out about unauthorized immigration. See Hainmueller and Hangartner (2013) for a discussion.
} 
higher. We also find that higher income individuals are more in favor of restricting spending on social programs available to the unauthorized where the numbers of the unauthorized in their county are high. Furthermore, we find that this is true even when we control for the Hispanic share of the population. This evidence continues to offer support that there is a positive association between a greater presence of unauthorized immigrants and more restrictive attitudes towards fiscal services. Additionally, we also find that this result persists even when we include a measure for partisanship, controlling for those respondents who self identify as Republicans. This suggests that our results hold broadly for other respondents, such as Independents, Democrats and undecided respondents. We also account for whether or not respondents might be concerned about "law breaking” by including a measure of respondents' willingness to use U.S. military troops to uphold international law. Our results still hold.

Finally, we also account for whether or not the individual respondent has a job or not. We find that while employment status is not a predictor of whether or not someone wants to restrict the unauthorized from using social services, it is a predictor of whether or not someone supports spending on Medicaid and Medicare. This provides further evidence that employment changes, such as losing one's job, are statistically related to holding more protectionist views on fiscal policy rather than anti-immigrant views induced by labor market competition. Like our results reported above that analyze voting behavior, we find no evidence that lower income individuals hold more anti-immigrant sentiments and that it is the wealthier rather than the poor that are more likely to express anti-immigrant sentiments sourced in economic concerns. ${ }^{17}$

\footnotetext{
${ }^{17}$ We also examine the affect of the share of unauthorized immigrants on Republican voter intent and also Republican voter recall and present these results in Table A.2 in the Appendix. The findings support the original specification, however, the interaction is no longer statistically significant, likely due to a reduction in the number of observations available for computation. For example, even the Republican party ID variable, which is the most robust predictor of Republican voting behavior, is no longer a significant predictor of Republican voter intent, despite the positive correlation between Republican party ID and Republican voter intent. There are also some well known methodological problems with the voter intent and voter recollection variables. For voter intent, over one-third of respondents answered the question about how they would vote in the upcoming election as "Don't know." This makes statistical analysis difficult as a large share of the survey respondents have missing data. Secondly, with the vote recollection question, its well understood that vote recall data can suffer both from over-representation of actual voters among survey respondents and also vote over-reporting by actual nonvoters (Sciarini and Goldberg, 2016).
} 
In summary, we theorize that one channel through which a larger presence of unauthorized immigrants produces stronger support for the Republican party in the U.S. is due to a fear that growing income inequality will lead to efforts for greater degrees of redistribution (i.e., through higher tax rates on the wealthy). We see in Table 2 that wealthier counties react more strongly to larger numbers of unauthorized, providing some evidence that redistributive threats are at work. Using survey data for 2012, we also find that those with higher incomes are more likely to oppose the unauthorized using social services when respondents live in counties with high number of the unauthorized. While researchers have been quick to point out a lack of a statistical relationship between the number of immigrants and higher tax contributions as evidence against the fiscal burden hypothesis, we find instead that, conditional on the unauthorized being present, wealthier rather than poorer voters are more likely to shift their allegiance to the right.

\section{CONCLUSION}

Due to a lack of data, no empirical study has been able to examine whether voters respond to an influx of low skilled unauthorized immigration with greater appetites for protection in the United States over time while holding other concerns, such as racial prejudice against Hispanics, constant. ${ }^{18}$ We find a significant positive correlation between larger shares of unauthorized immigration and electoral support for Republicans in counties with at least the sample median share of unauthorized. This is in addition to general voter opposition to Hispanics-the ethnic group to which the majority of unauthorized immigrants in the U.S. belong. Furthermore, we find this response to be greater in richer counties, supporting a theory of redistributive fears as the mechanism driving the results.

We also provide evidence that the results are not being driven by composition bias of voters

\footnotetext{
${ }^{18}$ One analysis that comes close is Mayda, Peri, and Steingress (2015) who use state-level data to assess the impact of immigration generally on support for Democrats and Republicans.
} 
in the county, as the presence of the unauthorized is not statistically related to migration patterns. Similarly, we also examine whether or not historical prejudice as opposed to contemporary patterns of prejudice may be driving the results. Finally, we test whether or not our results are consistent with evidence at the individual level. As in the cross sectional time series analysis, we find that it is richer individuals who are more likely to respond negatively toward the unauthorized, while accounting for whether or not such opposition is based on concerns such as party affiliation, upholding the rule of law, or employment status.

Our research design has a number of important features and our results help build further support for theories of material interest alongside theories of racial and ethnic prejudice, which, according to our results, also matter. First, we are able to make use of unique administrative data that allows us to link a greater presence of unauthorized immigrants with changes in elections. Second, by examining county elections within a state, we are able to control for many of the institutional features that make cross-country or cross-state comparisons difficult and comparative analysis too blunt. Third, we know from previous work that the link between individual income and voting is particularly strong in the South and so an analysis using Georgia data is particularly well suited (Gelman, Shor, Bafumi et al., 2007). Fourth, because we are examining the effects of a non-voting population, we need not be concerned about the behavior of the population of interest confounding the results. Finally, by exploiting a long time series, we can characterize the pattern of the relationship over time.

As far as implications of the results in this paper beyond the borders of Georgia, given Georgia's prominence and similarity to other states in the South, our results should be generalizable to other states with similar dynamics. Of course, unauthorized immigration is only one issue voters consider when heading to the polls. If other issues loom larger for voters, especially if the population share of unauthorized immigrants is relatively small, the impact of unauthorized immigration on voters' behavior may be diluted. However, the issue of immigration does not seem to be going away. Immigration has become a defining issue in U.S. Republican politics, as it has for politicians 
in Germany, Switzerland, and Australia, just to name a few. Immigration touches on a number of central issues: nationalism, economics, culture, and national security. Our findings help shed light on growing tensions in many countries that have aging populations and growing income inequality. On the one hand, countries with aging populations and growing income inequality may need to increase immigration to sustain generous welfare spending such as health and retirement benefits. On the other hand, natives, and especially wealthy voters, may react to an influx of immigrants with higher appetites for protectionism. 


\section{References}

Abramowitz, Alan, Albert D Cover, and Helmut Norpoth. 1986. The President's Party in Midterm Elections: Going from Bad to Worse. American Journal of Political Science 30 (3):562-576.

Acharya, Avidit, Matthew Blackwell, and Maya Sen. 2016. The Political Legacy of American Slavery. The Journal of Politics 78 (3):000-000.

Alderson, Arthur S, and Francois Nielsen. 2002. Globalization and the Great U-Turn: Income Inequality Trends in 16 OECD Countries1. American Journal of Sociology 107 (5):1244-1299.

An, Brian P. 2015. The role of social desirability bias and racial/ethnic composition on the relation between education and attitude toward immigration restrictionism. The Social Science Journal $52(4): 459-467$.

Auerbach, Alan J, and Philip Oreopoulos. 1999. Analyzing the Fiscal Impact of US Immigration. American Economic Review 176-180.

Baum, C.R. 2008. Modeling Proportions. Stata Journal 8:299-303.

Bearce, David, and Jennifer Laks Hutnick. 2014. International Labor Mobility, Redistribution, and Domestic Political Liberalization. Economics \& Politics 26 (3):411-430.

Becker, Gary S. 1983. A Theory of Competition Among Pressure Groups for Political Influence. The Quarterly Journal of Economics 371-400.

Benabou, Roland, and Efe A Ok. 2001. Social Mobility and the Demand for Redistribution: The POUM Hypothesis. Quarterly Journal of Economics 116 (2).

Borjas, George J. 1987. Self-selection and the Earnings of immigrants. American Economic Review 77 (4):531-53.

1999. Immigration and Welfare Magnets. Journal of Labor Economics 17 (4):607-637. 
Borjas, George J., Richard B. Freeman, and Lawrence F. Katz. 1991. On the Labor Market Effects of Immigration and Trade. National Bureau of Economic Research 3761.

Bovbjerg, Barbara D. 2006. Social Security numbers: Coordinated Approach to SSN Data Could Help Reduce Unauthorized Work. Testimony before the Subcommittees on Social Security and on Oversight, Committee on Ways and Means, House of Representatives GAO-06- 458T Accessed December 2008, Available at http://www.gao.gov/new.items/d06458t.pdf.

Brader, Ted, Nicholas A Valentino, and Elizabeth Suhay. 2008. What triggers public opposition to immigration? Anxiety, group cues, and immigration threat. American Journal of Political Science 52 (4):959-978.

Burns, Peter, and James G Gimpel. 2000. Economic insecurity, prejudicial stereotypes, and public opinion on immigration policy. Political Science Quarterly 115 (2):201-225.

Campbell, Andrea Louise, Cara Wong, and Jack Citrin. 2006. Racial Threat, partisan climate, and direct democracy: Contextual effects in three California initiatives. Political Behavior 28 (2):129-150.

Card, David. 2009. Immigration and Inequality. American Economic Review 99 (2):1-21.

Card, David, Christian Dustmann, and Ian Preston. 2012. Immigration, Wages, and Compositional Amenities. Journal of European Economic Association 10 (1):2012.

Chavez, Leo. 2012. Shadowed lives: Undocumented immigrants in American society. Cengage Learning.

Cheung, Ron, and Chris Cunningham. 2011. Who Supports Portable Assessment Caps: The Role of Lock-in, Mobility, and Tax Share. Regional Science and Urban Economics 173-86. 
Citrin, Jack, Donald P Green, Christopher Muste, and Cara Wong. 1997. Public opinion toward immigration reform: The role of economic motivations. The Journal of Politics 59 (03):858881.

Committee on Ways and Means. 2004. Greenbook, WMCP 108-6, Section 4.

Cornelius, Wayne A. 1982. Interviewing undocumented immigrants: methodological reflections based on fieldwork in Mexico and the US. International Migration Review 378-411.

Corneo, Giacomo, and Hans Peter Gruner. 2000. Social Limits to Redistribution. American Economic Review 90 (5):1491-1507.

Couch, Kenneth A., and Dana W. Placzek. 2010. Earnings Losses of Displaced Workers Revisited. The American Economic Review 572-589.

Dancygier, Rafaela M, and Michael J Donnelly. 2013. Sectoral economies, economic contexts, and attitudes toward immigration. Journal of Politics 75 (01):17-35.

Facchini, Giovanni, and Anna Maria Mayda. 2009. Does the Welfare State Affect Individual Attitudes toward Immigrants? Evidence across Countries. The Review of Economics and Statistics 91 (2):295-314.

Fitzgerald, Jennifer, David Leblang, and Jessica C Teets. 2014. Defying the law of gravity: The Political Economy of International Migration. World Politics 66 (03):406-445.

Gelman, Andrew, Boris Shor, Joseph Bafumi, and David Park. 2007. Rich State, Poor State, RedState, Blue State: What's the Matter with Connecticut. Quarterly Journal of Political Science $2: 345-367$.

Goldstein, Judith L, and Margaret E Peters. 2014. Nativism or economic threat: Attitudes toward immigrants during the great recession. International Interactions 40 (3):376-401. 
Hainmueller, Jens, and Dominik Hangartner. 2013. Who gets a Swiss passport? A natural experiment in immigrant discrimination. American Political Science Review 107 (01):159-187.

Hainmueller, Jens, and Michael Hiscox. 2010. Attitudes towards Highly Skilled and Lowskilled Immigration: Evidence from a Survey Experiment. American Political Science Review 104 (1):61-84.

Hajnal, Zoltan, and Michael U Rivera. 2014. Immigration, Latinos, and white partisan politics: The new democratic defection. American Journal of Political Science 58 (4):773-789.

Hanson, Gordon, Kenneth Scheve, and Mathew Slaughter. 2007. Public Finance and Individual Preferences Over Globalization Strategies. Economics and Politics 19:1-33.

Hatton, Timothy J, and Jeffrey G Williamson. 1998. The age of mass migration: An economic analysis.

Hirschfeld Davis, Julie, and Julia Preston. 2016. What Donald Trumps Vow to Deport Up to 3 Million Immigrants Would Mean.

Hoefer, Michael, Nancy Rytina, and Bryan C. Baker. 2012. Estimates of the Unauthorized Immigrant Population Residing in the United States: January 2010. Policy directorate, Office of Immigration Statistics, U.S. Department of Homeland Security.

Hood III, MV, and Irwin L Morris. 1998. Give us your tired, your poor,... but make sure they have a green card: The effects of documented and undocumented migrant context on Anglo opinion toward immigration. Political Behavior 20 (1):1-15.

Hopkins, Daniel J, Van C Tran, and Abigail Fisher Williamson. 2014. See no Spanish: language, local context, and attitudes toward immigration. Politics, Groups, and Identities 2 (1):35-51. 
Hotchkiss, Julie L., and Myriam Quispe-Agnoli. 2013. The Expected Impact of State Immigration Legislation on Labor Market Outcomes. Journal of Policy Analysis and Management 32 (1):3459.

Huse, James. G. 2002. Status of the Social Security Administrations Earnings Suspense File. Social Security Administration Congressional Response Report Accessed December 2009, A-03-0323038 Available at http://oig.ssa.gov/sites/default/files/audit/full/html/A-03-03-23038.html.

Jackson, Robert A, Robert D Brown, and Gerald C Wright. 1998. Registration, turnout, and the electoral representativeness of US state electorates. American Politics Research 26 (3):259-287.

Johnson, Mary. 2007. The Growing Cost of Illegal Immigrants to Social Security: Unprecedented Growth in Social Securitys Earnings Suspense File. The Senior Citizens League .

King, Gary. 1997. A Solution to the Ecological Inference Problem: Reconstructing Individual Behavior from Aggregate Data. Princeton: Princeton University Press.

Knight, Brian G. 2014. An Econometric Evaluation of Competing Explanations for The Midterm Gap. Working Paper 20311, National Bureau of Economic Research.

Krogstad, Jens Manuel, and Jeffrey S Passel. 2014. 5 Facts about Illegal Immigration in the US. Pew Research Center .

Maddala, G.S. 1983. Limited Dependent and Qualitative Variables in Econometrics. Cambridge: Cambridge University Press.

Malhotra, Neil, Yotam Margalit, and Cecilia Hyunjung Mo. 2013. Economic Explanations for Opposition to Immigration: Distinguishing between Prevalence and Conditional Impact. American Journal of Political Science 57 (2):391-410.

Mandelman, Federico, and Courtney Nosal. 2008. Remittances ebb and flow with the immigration tide. EconSouth . 
Margalit, Yotam. 2012. Lost in Globalization: International Economic Integration and the Sources of Popular Discontent1. International Studies Quarterly 56 (3):484-500.

Mayda, Anna Maria. 2006. Who is Against Immigration? A Cross Country Investigation of Individual Attitudes Towards Immigrants. The Review of Economics and Statistics 88 (3):510530.

Mayda, Anna Maria, Giovanni Peri, and Walter Steingress. 2015. Immigration to the US: A Problem for the Republicans or the Democrats? Tech. rep., Institute for the Study of Labor (IZA).

McCarty, Nolan, Keith T Poole, and Howard Rosenthal. 2003. Political polarization and income inequality. Available at SSRN 1154098 .

Mendelberg, Tali. 2001. The race card: Campaign strategy, implicit messages, and the norm of equality. Princeton University Press.

MIF. April 2008. 2008 Survey of U.S. Remittance Senders to LAC, Bendixen and Associates.

MORI, Ipsos. 2014. Perceptions are not reality: Things the world gets wrong. Online. Https://www.ipsos-mori.com/researchpublications/researcharchive/3466/Perceptions-arenot-reality-10-things-the-world-gets-wrong.aspx.

Muller, Thomas, and Thomas J. Espenshade. 1985. A Review of State Immigration Legislation in 2005. The Fourth Wave. The Urban Institute Press. Http://www.ncsl.org/issuesresearch/immig/state-laws-related-to-immigration-andimmigrants.aspx.

NCSL. 2005. A Review of State Immigration Legislation in 2005. Washington, D.C.: National Conference of State Legislator. Http://www.ncsl.org/research/immigration/immigrant-policyproject-state-legislation-117.aspx.

Newman, Benjamin J, and Yamil Velez. 2014. Group Size versus Change? Assessing Americans’ Perception of Local Immigration. Political Research Quarterly 67 (2):293-303. 
Nickell, Stephen. 1981. Biases in Dynamic Models with Fixed Effects. Econometrica 49 (6):147126.

O’Connell, Heather A. 2012. The Impact of Slavery on Racial Inequality in Poverty in the Contemporary U.S. South. Social Forces 90 (3):713-734.

OECD. 2013. International Migration Outlook 2013. Paris: OECD Publishing.

Passel, Jeffery S., and D’Vera Cohn. 2009. A Portrait of Unauthorized Immigrants in the United States. Pew Hispanic Center Report.

Passel, Jeffrey S., D’Vera Cohn, Jens Manuel Krogstad, and Ana Gonzalez-Barrera. 2014. As Growth Stalls, Unauthorized Immigrant Population Becomes More Settled. Pew Research Center. Http://www.pewhispanic.org/2014/09/03/as-growth-stalls-unauthorized-immigrantpopulation-becomes-more-settled/.

Passel, Jeffrey S., DVera Cohn, and Ana Gonzalez-Barrera. 2013. Population Decline of Unauthorized Immigrants Stalls, May Have Reversed. Pew Hispanic Center, Washington D.C.

Perez, Efren. 2010. Explicit Evidence on the Impact of Implicit Attitudes: The IAT and Immigration Policy Judgments. Political Behavior 32 (4):517-545.

Reece, Robert L, and Heather A OConnell. 2016. How the Legacy of Slavery and Racial Composition Shape Public School Enrollment in the American South. Sociology of Race and Ethnicity $2(1): 42-57$.

Roemer, John E, et al. 1995. Why the poor do not expropriate the rich in democracies: A new argument. Working Paper .

Sanchez, George J. 1997. Face the nation: Race, immigration, and the rise of nativism in late twentieth century America. International Migration Review 1009-1030. 
Scheve, Kenneth, and Matthew Slaughter. 2001. Labor Market Competition and Individual Preferences Over Immigration Policy. The Review of Economics and Statistics 83 (1):133-145.

Sciarini, Pascal, and Andreas C Goldberg. 2016. Turnout Bias in Postelection Surveys: Political Involvement, Survey Participation, and Vote Overreporting. Journal of Survey Statistics and Methodology smv039.

Tingley, Dustin. 2013. Public Finance and Immigration Preferences: A Lost Connection? Polity 45 (1):4-33.

Tolbert, Caroline J., and Rodney Hero. 1996. Race/Ethnicity and Direct Democracy: An Analysis of Californias Illegal Immigration Initiative. The Journal of Politics 58:806-818.

Tolsma, Jochem, Marcel Lubbers, and Marcel Coenders. 2008. Ethnic competition and opposition to ethnic intermarriage in the Netherlands: A multi-level approach. European Sociological Review 24 (2):215-230.

Valentino, Nicholas A, Ted Brader, and Ashley E Jardina. 2013. Immigration Opposition among US Whites: General Ethnocentrism or Media Priming of Attitudes about Latinos? Political Psychology 34 (2):149-166.

Valentino, Nicholas A, Vincent L Hutchings, and Ismail K White. 2002. Cues that matter: How political ads prime racial attitudes during campaigns. American Political Science Review 96 (01):75-90.

Warren, Robert, and John Robert Warren. 2013. Unauthorized Immigration to the United States: Annual Estimates and Components of Change, by State, 1990 to 2010. International Migration Review 47(2):296-329.

$\mathrm{Xu}$, Ping, James C Garand, and Ling Zhu. 2015. Imported Inequality? Immigration and Income Inequality in the American States. State Politics \& Policy Quarterly . 
Zingher, Joshua N, and M Steen Thomas. 2014. The Spatial and Demographic Determinants of Racial Threat. Social Science Quarterly 95 (4):1137-1154. 
Table 1: Average annual growth, 1994-2008, in U.S. and GA employment, Hispanic workers, and workers identified as undocumented.

\begin{tabular}{l|c}
\hline \hline & $\begin{array}{c}\text { Average Annual } \\
\text { Growth Rate of: }\end{array}$ \\
\hline Total number of workers in the U.S & $1.43 \%$ \\
Total number of foreign born, Hispanic workers in the U.S. & $7.26 \%$ \\
Total number of workers in Georgia & $2.82 \%$ \\
Total number of foreign born, Hispanic workers in Georgia & $20.74 \%$ \\
Total number of workers in GA identified as undocumented & $29.65 \%$ \\
\hline \hline
\end{tabular}

Note: Average annual growth, 1994-2008, in U.S. and GA employment, Hispanic workers, and workers identified as undocumented. Current Population Survey, Basic Survey (March), 1994-2008; and authors' calculations. 1994 is used as the base year since it is the first year the Current Population Survey has a reliable indicator of Hispanic ethnicity. 


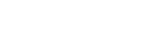

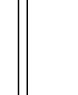

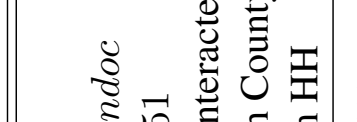

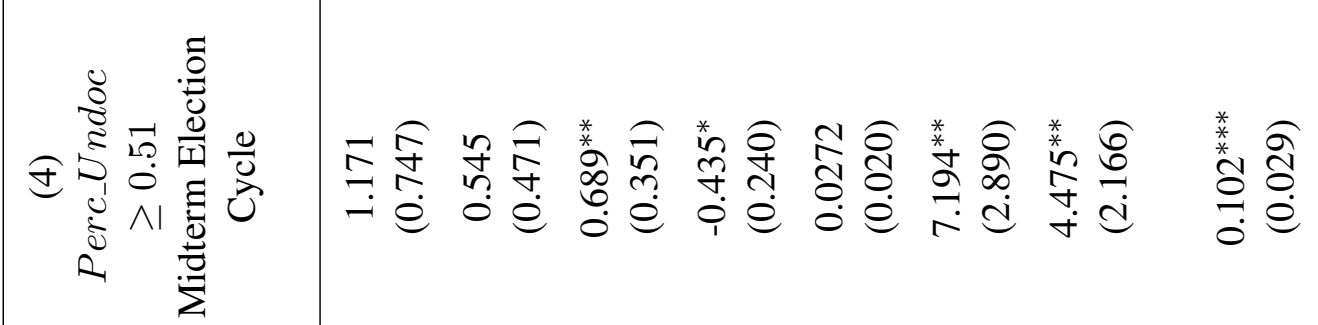

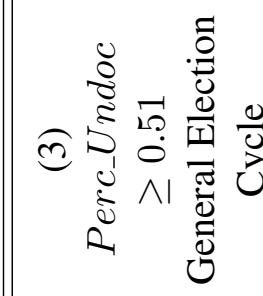

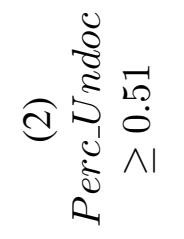

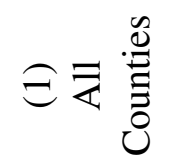

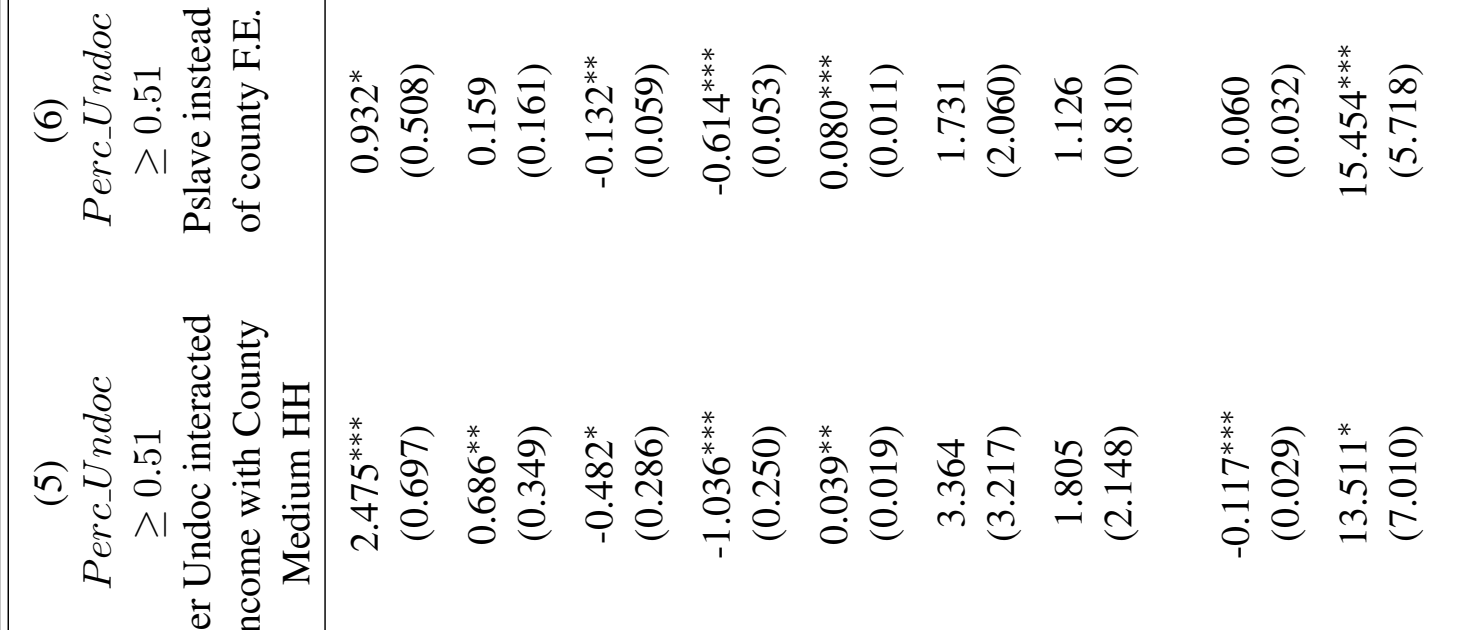


Table 3: Granger Causality Test

\begin{tabular}{|c|c|c|}
\hline Dependent Variable & Percent Undocumented & Percent Republican Votes \\
\hline \multirow[t]{2}{*}{ PercentUndocumented $_{t-1}$} & $0.830 * * *$ & $0.015^{*}$ \\
\hline & $(-0.071)$ & $(-0.008)$ \\
\hline \multirow{2}{*}{ PercentUndocumented $_{t-2}$} & 0.015 & -0.004 \\
\hline & $(-0.101)$ & $(-0.010)$ \\
\hline \multirow{2}{*}{ PercentUndocumented $_{t-3}$} & 0.172 & $-0.016^{* *}$ \\
\hline & $(-0.124)$ & $(-0.008)$ \\
\hline \multirow{2}{*}{ ShareRepublicanVotes $_{t-1}$} & 0.000 & $0.001 * * *$ \\
\hline & $(-0.000)$ & $(-0.000)$ \\
\hline \multirow{2}{*}{ ShareRepublicanVotes $_{t-2}$} & 0.000 & $0.001 * * *$ \\
\hline & $(-0.001)$ & $(-0.000)$ \\
\hline \multirow{2}{*}{${\text { ShareRepublicanV } \text { otes }_{t-3}}$} & -0.000 & $0.000 * *$ \\
\hline & $(-0.001)$ & $(-0.000)$ \\
\hline \multirow[t]{2}{*}{ PercentBlack $(0-1)$} & $-0.215 * * *$ & $-0.567 * * *$ \\
\hline & $(-0.082)$ & $(-0.032)$ \\
\hline \multirow[t]{2}{*}{ Constant } & $0.254 * * *$ & $0.593 * * *$ \\
\hline & -0.073 & -0.027 \\
\hline Observations & 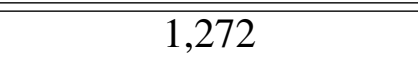 & 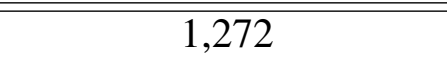 \\
\hline R-squared & 0.841 & 0.369 \\
\hline F-stat lagged Republican vote & 0.125 & \\
\hline p-value lagged Republican vc & es zero $\quad 0.945$ & \\
\hline \multicolumn{2}{|c|}{ F-stat lagged percent undocumented zero } & 2.374 \\
\hline \multicolumn{2}{|c|}{ p-value lagged percent undocumented zero } & 0.069 \\
\hline
\end{tabular}

Note: Robust standard errors in parentheses. Unit of observation is the county. ${ }^{* * *} p<0.001,{ }^{* *} p<0.01,{ }^{*} p<0.05$ statistically different from zero at the 90th, 95th, and 99th percent confidence levels. 
Table 4: GLM Logistic Regression of Migration, Congressional Elections 2005-2010

\begin{tabular}{lcc}
\hline \hline Dependent Variable & Out-migration & In-migration \\
\hline Lagged Percent Undoc & 0.169 & -0.210 \\
MedianH H & $(0.229)$ & $(0.270)$ \\
Income $(\$ 00000)$ & $0.089 * *$ & 0.072 \\
Percent Black $(0-1)$ & $(0.043)$ & $(0.090)$ \\
& $-0.353^{* *}$ & $-0.819 * * *$ \\
Annual empl growth & $(0.136)$ & $(0.247)$ \\
in county $(0-1)$ & 0.102 & 0.048 \\
Near county & $(0.143)$ & $(0.239)$ \\
simple average & 0.146 & 0.440 \\
percent undoc & $(0.385)$ & $(0.653)$ \\
Lagged Share & & \\
of Votes Going & -0.008 & $-0.042 * * *$ \\
to Republicans $(0-1)$ & $(0.005)$ & $(0.008)$ \\
Lagged outflow percent & $-0.679 * * *$ & \\
Lagged inflow percent & $(0.216)$ & \\
Observations & & 0.147 \\
\hline \hline
\end{tabular}

Note: Table contains estimated marginal effects and their robust standard errors in parentheses. Direct parameter estimates available upon request. ${ }^{* * *} p<0.001,{ }^{* *} p<0.01,{ }^{*} p<0.05$ statistically different from zero at the 90th, 95th, and 99th percent confidence levels. Dependent variable is the percent of population in county that out or in migrated. Unit of observation is the county. Regressions include county and year fixed effects. 
Table 5: Maximum Likelihood Logit Estimation of Restrictions to Immigration with UnauthorizedIncome Interaction

\begin{tabular}{|c|c|c|c|c|}
\hline & \multicolumn{4}{|c|}{ Dependent variable $=$ Opposed to: } \\
\hline & $\begin{array}{l}\text { Social Services } \\
\text { for Illegals }\end{array}$ & $\begin{array}{c}\text { Gay } \\
\text { Marriage }\end{array}$ & $\begin{array}{c}\text { Gun } \\
\text { Control }\end{array}$ & $\begin{array}{c}\text { Spending on } \\
\text { Medicaid and Medicare }\end{array}$ \\
\hline Male $(0,1)$ & $\begin{array}{l}0.244^{* *} \\
(0.121)\end{array}$ & $\begin{array}{l}1.228^{* * *} \\
(0.165)\end{array}$ & $\begin{array}{l}0.570^{* * *} \\
(0.122)\end{array}$ & $\begin{array}{l}0.617^{* * *} \\
(0.145)\end{array}$ \\
\hline Highschool $(0,1)$ & $\begin{array}{l}-0.046 \\
(0.145)\end{array}$ & $\begin{array}{c}-0.311^{*} \\
(0.183)\end{array}$ & $\begin{array}{c}-0.202 \\
(0.144)\end{array}$ & $\begin{array}{c}0.583^{* * *} \\
(0.167)\end{array}$ \\
\hline Some College $(0,1)$ & $\begin{array}{l}0.267^{*} \\
(0.154)\end{array}$ & $\begin{array}{c}-0.471^{* *} \\
(0.210)\end{array}$ & $\begin{array}{c}0.227 \\
(0.156)\end{array}$ & $\begin{array}{l}-0.226 \\
(0.204)\end{array}$ \\
\hline CollegeGrad $(0,1)$ & $\begin{array}{c}0.906^{* *} \\
(0.436)\end{array}$ & $\begin{array}{c}0.096 \\
(0.549)\end{array}$ & $\begin{array}{c}0.609 \\
(0.481)\end{array}$ & $\begin{array}{l}-0.309 \\
(0.645)\end{array}$ \\
\hline Republican $(0,1)$ & $\begin{array}{c}0.946^{* * *} \\
(0.127)\end{array}$ & $\begin{array}{c}0.966^{* * *} \\
(0.159)\end{array}$ & $\begin{array}{c}1.559^{* * *} \\
(0.144)\end{array}$ & $\begin{array}{c}0.818^{* * *} \\
(0.150)\end{array}$ \\
\hline InternationalLaw $(0,1)$ & $\begin{array}{c}-0.485^{* * *} \\
(0.132)\end{array}$ & $\begin{array}{c}-1.119^{* * *} \\
(0.204)\end{array}$ & $\begin{array}{c}-0.593^{* * *} \\
(0.126)\end{array}$ & $\begin{array}{c}-0.951^{* * *} \\
(0.175)\end{array}$ \\
\hline Employed $(0,1)$ & $\begin{array}{c}0.003 \\
(0.129)\end{array}$ & $\begin{array}{c}0.013 \\
(0.166)\end{array}$ & $\begin{array}{c}-0.238^{*} \\
(0.130)\end{array}$ & $\begin{array}{c}0.421^{* * *} \\
(0.149)\end{array}$ \\
\hline Income $(0: 7)$ & $\begin{array}{c}0.024 \\
(0.024)\end{array}$ & $\begin{array}{l}-0.003 \\
(0.032)\end{array}$ & $\begin{array}{c}0.021 \\
(0.024)\end{array}$ & $\begin{array}{c}0.011 \\
(0.029)\end{array}$ \\
\hline Undoc $\geq 3 \%(0-1)$ & $\begin{array}{l}-1.637 \\
(1.174)\end{array}$ & $\begin{array}{l}-0.030 \\
(1.194)\end{array}$ & $\begin{array}{c}0.330 \\
(1.007)\end{array}$ & $\begin{array}{c}0.154 \\
(1.142)\end{array}$ \\
\hline Percent Hispanic (0-1) & $\begin{array}{c}-0.017 \\
(0.011)\end{array}$ & $\begin{array}{c}0.007 \\
(0.013)\end{array}$ & $\begin{array}{c}-0.021^{* *} \\
(0.011)\end{array}$ & $\begin{array}{c}0.018 \\
(0.012)\end{array}$ \\
\hline Undoc $\geq 3 \% *$ Income & $\begin{array}{c}0.453^{* *} \\
(0.214)\end{array}$ & $\begin{array}{c}0.122 \\
(0.216)\end{array}$ & $\begin{array}{c}0.035 \\
(0.187)\end{array}$ & $\begin{array}{c}0.075 \\
(0.206)\end{array}$ \\
\hline Constant & $\begin{array}{c}-0.975^{* * *} \\
(0.196)\end{array}$ & $\begin{array}{c}-2.218^{* * *} \\
(0.265)\end{array}$ & $\begin{array}{l}-0.116 \\
(0.192)\end{array}$ & $\begin{array}{c}-2.223^{* * *} \\
(0.249)\end{array}$ \\
\hline Observations & 1,343 & 1,341 & 1,334 & 1,308 \\
\hline Log Likelihood & -810.321 & -525.977 & -804.439 & -604.279 \\
\hline Akaike Inf. Crit. & $1,644.642$ & $1,075.954$ & $1,632.878$ & $1,232.559$ \\
\hline
\end{tabular}




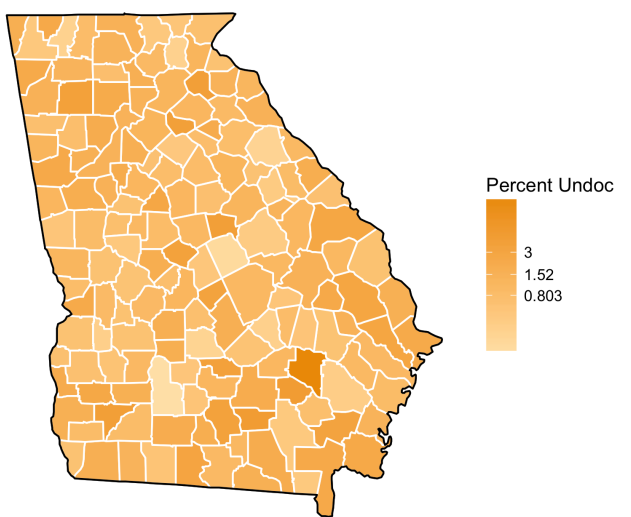

(a) Counties with percent of population identified as undocumented

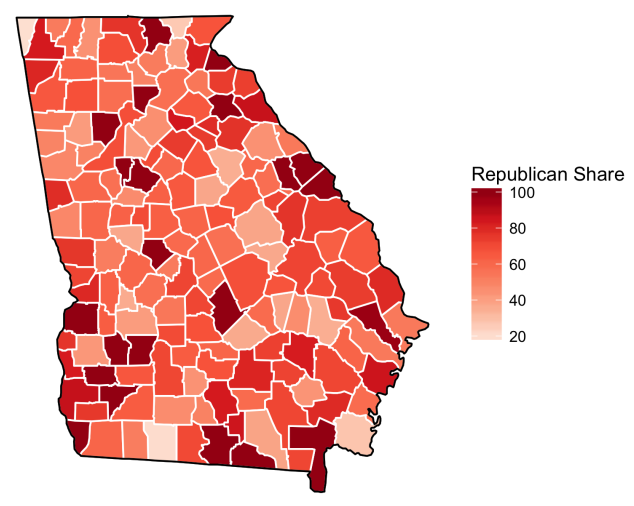

(b) Percent of the Republican vote share across counties

Figure 1: Distribution of average share of identified undocumented workers across counties and Republican vote share across counties in the U.S. state of Georgia in 2010. 


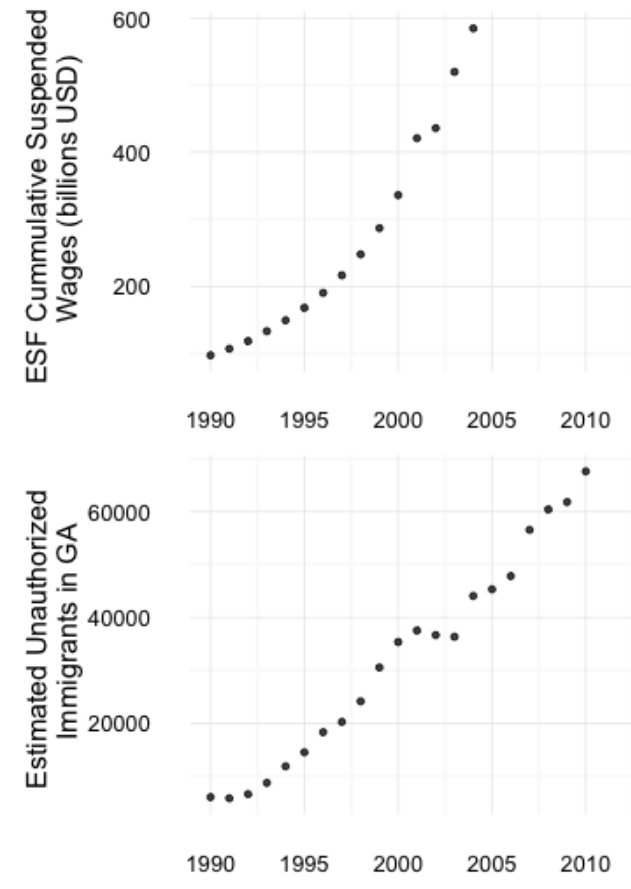

(a) Growth in Cumulative ESF and the number of GA workers identified as undocumented
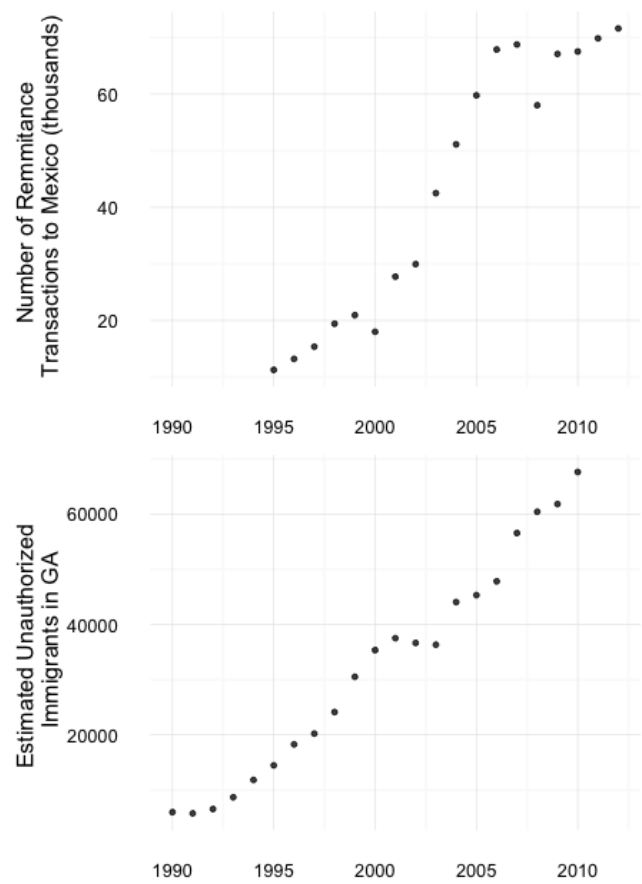

(b) Remittance transactions to Mexico and number of GA workers identified as undocumented.

Figure 2: Source: Huse (2002) for estimates 1990-2000, Johnson (2007) for estimates 2001-2004, and authors calculations. Dollar estimates reflect 2006 values, using the PCE chain-weighted deflator. Remittance transactions from Central Bank of Mexico, remittance database. 

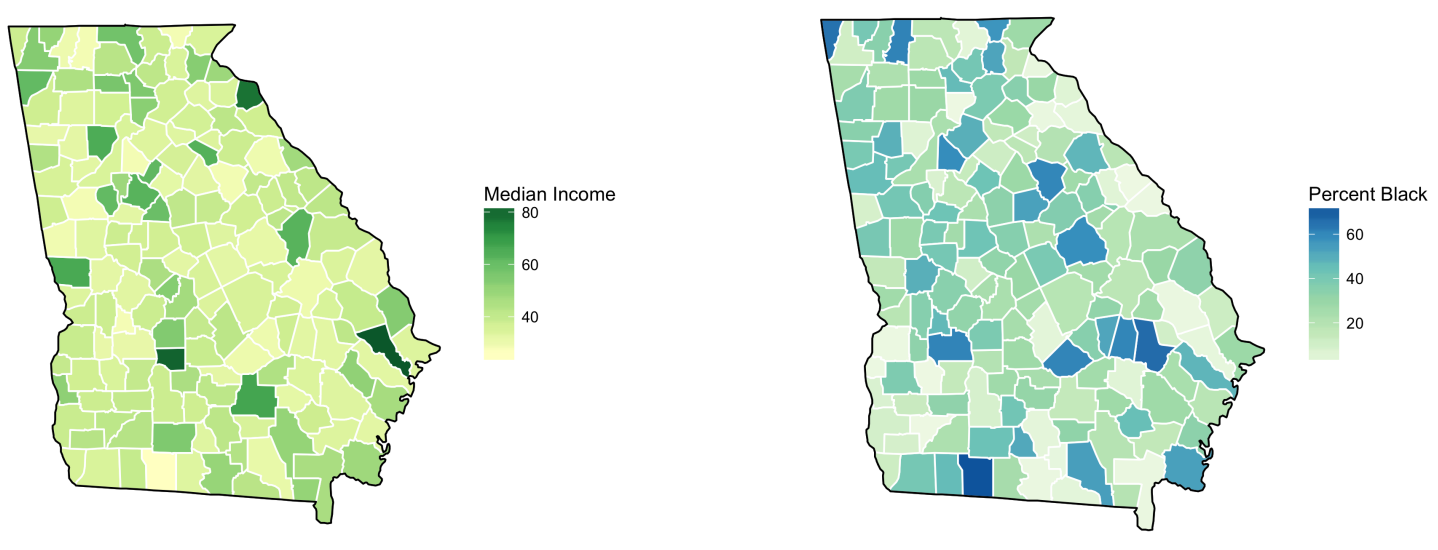

(a) County median household income (thousands of U.S. dollars)

(b) County population share of blacks (percentage)

Figure 3: Median Household Income and Population Share of Blacks in Georgia $2010(\rho=-0.41)$. 


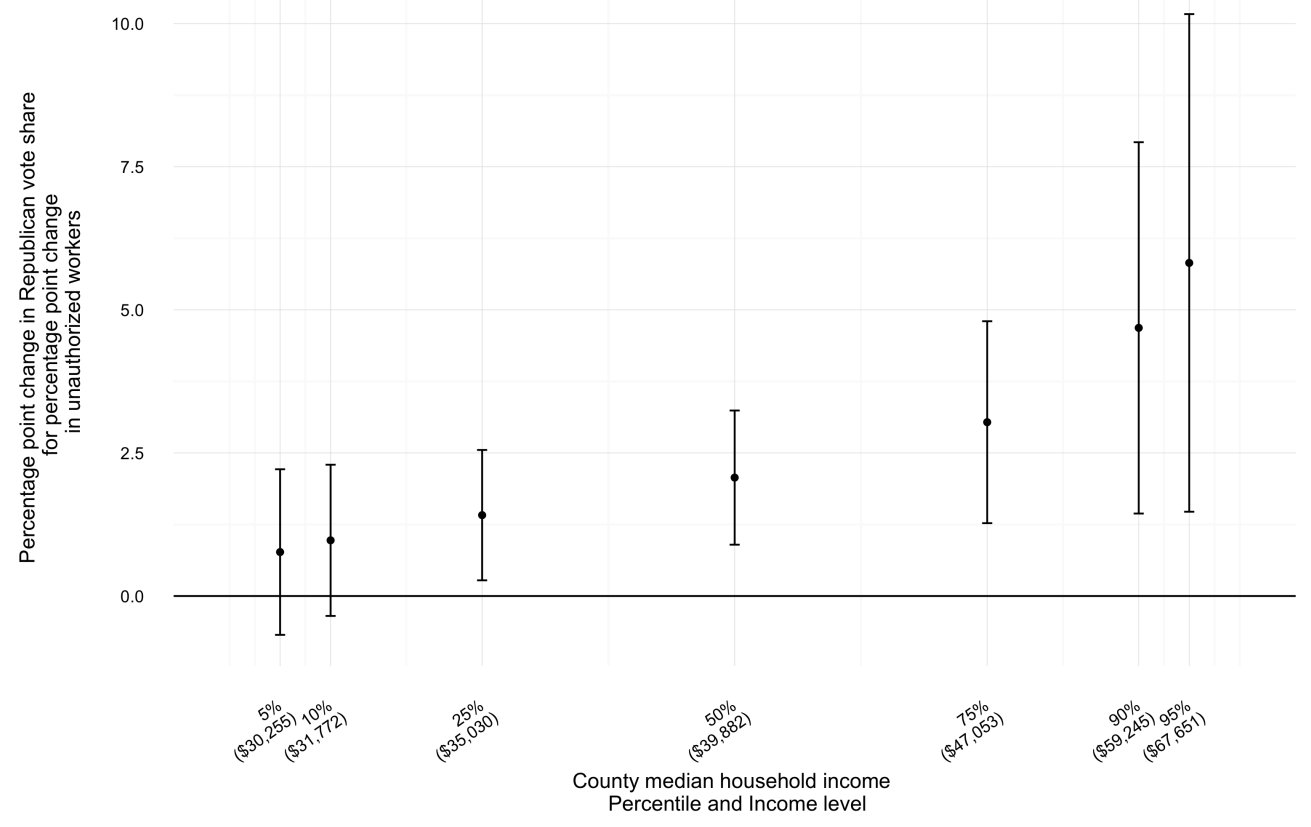

Figure 4: Marginal Effect of Income and the Unauthorized on Republican Vote Share 


\section{A Appendix}

Table A.1: Impact on Republican vote share, PerUndoc $\geq 0.51$ for all Elections

\begin{tabular}{lccc}
\hline \hline Variables & $\begin{array}{c}\text { Congressional } \\
\text { Elections }\end{array}$ & $\begin{array}{c}\text { Senatorial } \\
\text { Elections }\end{array}$ & $\begin{array}{c}\text { Gubernatorial } \\
\text { Elections }\end{array}$ \\
\hline Percent & $2.475 * * *$ & $0.866 * * *$ & 0.449 \\
Undoc $(0-1)_{t-2}$ & $(0.697)$ & $(0.251)$ & $(0.326)$ \\
Median HH Income & $-0.482^{*}$ & 0.078 & 0.136 \\
& $(0.286)$ & $(0.068)$ & $(0.130)$ \\
Percent Undocumented & $13.510 *$ & $4.903 * *$ & $6.335 * *$ \\
interacted with & $(7.010)$ & $(1.883)$ & $(3.041)$ \\
Median HH Income & & & $0.266 * *$ \\
Percent & $0.686 *$ & 0.0547 & $(0.120)$ \\
Hispanic $(0-1)_{t-2}$ & $(0.349)$ & $(0.094)$ & $-0.902 * * *$ \\
Percent Black $(0-1)$ & $-1.036 * * *$ & $-0.474 * * *$ & $(0.099)$ \\
& $(0.250)$ & $(0.060)$ & $0.070 * * *$ \\
Republican & $0.039 * *$ & $0.073 * * *$ & $(0.014)$ \\
Incumbent $(0,1)$ & $(0.019)$ & $(0.007)$ & $3.120 * * *$ \\
Annual empl growth & 3.364 & 0.798 & $(1.069)$ \\
incounty $(0-1)$ & $(3.217)$ & $(0.643)$ & -0.274 \\
Near county & 1.805 & 0.820 & $(0.897)$ \\
simple average & $(2.148)$ & $(0.514)$ & $464 *$ \\
percent undocumented & & & $(0.036)$ \\
Lagged Dep & $(0.029)$ & 621 & \\
Variable & 870 & $0.420 * * *$ & \\
Observations & & & \\
\hline \hline
\end{tabular}

Note: Table contains estimated marginal effects and their robust standard errors in parentheses. Direct parameter estimates available upon request. $* * * p<0.01, * * p<0.05$, $* p<0.1$ statistically different from zero at the 90th, 95th, and 99th percent confidence levels. Dependent variable is the percent of the vote going to Republicans. Unit of observation is the county. Regressions include county and year fixed effects. General elections occur in years when there is a presidential election. 
Table A.2: Impact of Undocumented Workers on Republican Vote Intent and Vote Recall

\begin{tabular}{|c|c|c|c|}
\hline & \multicolumn{3}{|c|}{ Dependent variable: } \\
\hline & $\begin{array}{c}\text { Republican Intent } \\
\text { (1) }\end{array}$ & $\begin{array}{c}\text { Republican Recall } \\
\text { (2) }\end{array}$ & $\begin{array}{c}\text { Opposed Immigration } \\
\text { (3) }\end{array}$ \\
\hline Male $(0,1)$ & $\begin{array}{c}0.058 \\
(0.142)\end{array}$ & $\begin{array}{c}0.086 \\
(0.147)\end{array}$ & $\begin{array}{l}0.244^{* *} \\
(0.121)\end{array}$ \\
\hline Highschool $(0,1)$ & $\begin{array}{c}0.044 \\
(0.166)\end{array}$ & $\begin{array}{c}0.105 \\
(0.174)\end{array}$ & $\begin{array}{l}-0.046 \\
(0.145)\end{array}$ \\
\hline SomeCollege $(0,1)$ & $\begin{array}{l}-0.075 \\
(0.180)\end{array}$ & $\begin{array}{c}0.058 \\
(0.187)\end{array}$ & $\begin{array}{l}0.267^{*} \\
(0.154)\end{array}$ \\
\hline CollegeGraduate $(0,1)$ & $\begin{array}{l}-0.492 \\
(0.560)\end{array}$ & $\begin{array}{c}0.287 \\
(0.630)\end{array}$ & $\begin{array}{c}0.906^{* *} \\
(0.436)\end{array}$ \\
\hline Republican $(0,1)$ & $\begin{array}{c}0.262 \\
(0.160)\end{array}$ & $\begin{array}{c}0.358^{* *} \\
(0.164)\end{array}$ & $\begin{array}{c}0.946^{* * *} \\
(0.127)\end{array}$ \\
\hline InternationalLaw $(0,1)$ & $\begin{array}{l}-0.167 \\
(0.148)\end{array}$ & $\begin{array}{l}-0.030 \\
(0.156)\end{array}$ & $\begin{array}{c}-0.485^{* * *} \\
(0.132)\end{array}$ \\
\hline Employed $(0,1)$ & $\begin{array}{c}-0.033 \\
(0.151)\end{array}$ & $\begin{array}{c}-0.136 \\
(0.155)\end{array}$ & $\begin{array}{c}0.003 \\
(0.129)\end{array}$ \\
\hline Income $(0: 7)$ & $\begin{array}{l}-0.019 \\
(0.028)\end{array}$ & $\begin{array}{l}-0.037 \\
(0.029)\end{array}$ & $\begin{array}{c}0.024 \\
(0.024)\end{array}$ \\
\hline Undoc $\geq 3 \%(0,1)$ & $\begin{array}{l}-0.489 \\
(1.055)\end{array}$ & $\begin{array}{l}-1.293 \\
(1.391)\end{array}$ & $\begin{array}{l}-1.637 \\
(1.174)\end{array}$ \\
\hline PercentHispanic (0-1) & $\begin{array}{l}-0.014 \\
(0.013)\end{array}$ & $\begin{array}{l}-0.002 \\
(0.014)\end{array}$ & $\begin{array}{l}-0.017 \\
(0.011)\end{array}$ \\
\hline Undoc $\geq 3 \% *$ Income & $\begin{array}{c}0.056 \\
(0.208)\end{array}$ & $\begin{array}{c}0.255 \\
(0.262)\end{array}$ & $\begin{array}{c}0.453^{* *} \\
(0.214)\end{array}$ \\
\hline Constant & $\begin{array}{c}0.294 \\
(0.229)\end{array}$ & $\begin{array}{l}0.412^{*} \\
(0.239)\end{array}$ & $\begin{array}{c}-0.975^{* * *} \\
(0.196)\end{array}$ \\
\hline Observations & 838 & 796 & 1,343 \\
\hline Log Likelihood & -576.122 & -533.932 & -810.321 \\
\hline Akaike Inf. Crit. & $1,176.244$ & $1,091.863$ & $1,644.642$ \\
\hline
\end{tabular}

Note: Baseline Education is $<$ High School.

Robust standard errors in parentheses.

$* * * p<0.01, * * p<0.05, * p<0.1$ 
Table A.3: Relationship between Long-term Inequality and Unauthorized Immigration

(1)

$\mathrm{GDP}_{t-1} \quad$ State Welfare H-1 $_{t}$

Dependent Variable: Inequality (Gini Coefficient)

Percent undocumented workers w $_{t-1}$

$1.942^{*}$

$2.015^{*}$

(0.950)

(1.046)

Growth rate of real per capita income in $_{t}$

$-0.195$

(0.166)

State level public welfare spending, as $\%$ of Gross State Product P $_{t}$

0.818

(1.085)

Constant

$0.378 * * *$

$0.358 * * *$

(0.008)

(0.020)

Observations

19

19

R-squared

0.384

0.354

Standard errors in parentheses

$* * * \mathrm{p}<0.01, * * \mathrm{p}<0.05, * \mathrm{p}<0.1$

OLS regression for the state of Georgia, annual data, 1990 to 2011.

Dependent variable is State-level inequality (Gini) based on family income. 